\title{
Synthesis of an Anthracene-Based Macrocyclic Diphosphine Ligand
}

Martin-Louis Y. Riu, Wesley J. Transue, Ioana Knopf, and Christopher C. Cummins*

Massachusetts Institute of Technology, Cambridge, MA 02139, USA

\author{
Supporting Information
}

\section{Table of Contents}

S.1 Synthetic Details $\quad$ S.2

S.1.1 General Information . . . . . . . . . . . . . . . . . S.2

S.1.2 Synthesis of $\left[\mathrm{EtOP}_{2} \mathrm{~A}_{2}\right] \mathrm{AlCl}_{4}\left([2] \mathrm{AlCl}_{4}\right) \ldots \ldots \ldots \ldots \ldots \ldots \ldots$

S.1.2.1 NMR Characterization of the Crude Reaction Mixture . . . . . . . . . . S.6

S.1.3 Synthesis of $\left(\mathrm{PhPA}_{2}(\mathbf{3}) \ldots \ldots \ldots \ldots \ldots \ldots \ldots \ldots\right.$

S.1.4 Synthesis of $\left[\left(\mathrm{PhPA}_{2}\right] \mathrm{NiCl}_{2}(4)\right.$ in Dichloromethane . . . . . . . . . . . S.9

S.1.4.1 NMR Characterization of the Filtrate . . . . . . . . . . . S.10

S.1.4.2 Stability of 4 in Solution . . . . . . . . . . . . . S.11

S.1.4.3 Space-Filling Diagrams of $4 \ldots \ldots \ldots \ldots$. . . . . . . . . . . .

S.1.5 Synthesis of $\left\{\left[(\mathrm{PhPA})_{2}\right] \mathrm{NiCl}_{2}\left[\mathrm{~B}\left(\mathrm{C}_{6} \mathrm{~F}_{5}\right)_{4}\right]_{2}(\mathbf{5}) \ldots \ldots \ldots \ldots\right.$. . . . . . . . . .

S.1.5.1 Treatment of 5 with Acetonitrile . . . . . . . . . . . . . S.14

S.1.6 Preliminary Attempts to Synthesize an Organonickel Complex of 3 . . . . . . . . S.15

S.1.6.1 Treatment of 3 with (tmeda) $\mathrm{NiMe}_{2} \ldots \ldots \ldots \ldots$. . . . . . . . . . . . .

S.1.6.2 Treatment of 4 with Methylmagnesium Bromide . . . . . . . . . . . S.16

S.1.6.3 Treatment of 4 with Trimethylaluminum . . . . . . . . . . . S.17

$\begin{array}{llr}\text { S.2 X-Ray Diffraction Studies } & \text { S.18 }\end{array}$ 


\section{S.1 Synthetic Details}

\section{S.1.1 General Information}

Except as otherwise noted, all manipulations were performed in a Vacuum Atmospheres model MO$40 \mathrm{M}$ glovebox under an inert atmosphere of purified $\mathrm{N}_{2}$. All solvents were obtained anhydrous and oxygen-free by bubble degassing (Ar) and purification through columns of alumina using a solvent purification system (Pure Process Technology, Nashua, NH)[25] and storage over $4.0 \AA$ molecular sieves.[26] Deuterated solvents were purchased from Cambridge Isotope Labs, then degassed and stored over $4.0 \AA$ molecular sieves for at least $48 \mathrm{~h}$ prior to use. Diatomaceous earth (EM Science), $4.0 \AA$ molecular sieves, basic alumina, and charcoal were dried by heating above $200{ }^{\circ} \mathrm{C}$ under dynamic vacuum (50 mTorr) for at least $48 \mathrm{~h}$ prior to use. All glassware was dried in an oven for at least two hours at temperatures greater than $150{ }^{\circ} \mathrm{C}$.

Literature compounds EtOPA[12] (1) and (tmeda) $\mathrm{NiMe}_{2}[27] \quad\left(\right.$ tmeda $=N, N^{\prime}, N^{\prime}-$ tetramethylethylenediamine) were prepared according to reported procedures. Phenylmagnesium chloride solution (Sigma-Aldrich), aluminum(III) chloride (Alfa-Aesar), $\mathrm{K}\left[\mathrm{B}\left(\mathrm{C}_{6} \mathrm{~F}_{5}\right)_{4}\right]$ (AlfaAesar), (DME) $\mathrm{NiCl}_{2}$ (Strem Chemicals), methylmagnesium bromide solution (Sigma-Aldrich), and trimethylaluminum solution (Sigma-Aldrich) were used as received.

NMR spectra were obtained on a Jeol ECZ-500 instrument equipped with an Oxford Instruments superconducting magnet, on a Bruker Avance 400 instrument equipped with a Magnex Scientific or with a SpectroSpin superconducting magnet, or on a Bruker Avance 500 instrument equipped with a Magnex Scientific or with a SpectroSpin superconducting magnet. ${ }^{1} \mathrm{H}$ and ${ }^{13} \mathrm{C}$ NMR spectra were referenced internally to residual solvent signals. $[28]^{31} \mathrm{P}$ NMR spectra were externally referenced to $85 \% \mathrm{H}_{3} \mathrm{PO}_{4} \cdot{ }^{11} \mathrm{~B} \mathrm{NMR}$ spectra were externally referenced to $\mathrm{BF}_{3}-\mathrm{OEt}_{2}(0 \mathrm{ppm}) .{ }^{19} \mathrm{~F} \mathrm{NMR}$ spectra

were externally referenced to $\mathrm{CFCl}_{3}(0 \mathrm{ppm}) .{ }^{27} \mathrm{Al} \mathrm{NMR}$ spectra were externally referenced to $\mathrm{Al}\left(\mathrm{NO}_{3}\right)_{3}$ in $\mathrm{D}_{2} \mathrm{O}$. Elemental combustion analyses were performed by Midwest Micro Laboratories (Indianapolis, IN, USA). 


\section{S.1.2 Synthesis of $\left[\mathrm{EtOP}_{2} \mathrm{~A}_{2}\right] \mathrm{AlCl}_{4}\left([2] \mathrm{AlCl}_{4}\right)$}

Aluminum foil was used to limit exposure of the reaction mixture to ambient light during this experiment. Aluminum(III) chloride (2.62 g, $19.7 \mathrm{mmol}, 1.00$ equiv) was added portion wise to a thawing solution of EtOPA (5.00 g, $19.7 \mathrm{mmol}, 1.00$ equiv) in dichloromethane (100 mL). The solution was stirred at $23{ }^{\circ} \mathrm{C}$ for $24 \mathrm{~h}$, during which time the solution became pale yellow. The solution was filtered through a medium sintered frit $(15 \mathrm{~mL})$ containing a one inch plug of diatomaceous earth and all volatile materials were removed from the filtrate in vacuo. The resulting pale yellow solids were collected on a coarse sintered frit and the solids were washed with diethyl ether $(2 \times 25 \mathrm{~mL})$. Crystallization from minimal dichloromethane at $-35{ }^{\circ} \mathrm{C}$ provided yellow crystals of $[\mathbf{2}] \mathrm{AlCl}_{4}(3.90$ g, 6.16 mmol, 63\%). Elem. Anal. Calc'd(found) for $\mathrm{C}_{30} \mathrm{H}_{25} \mathrm{P}_{2} \mathrm{OAlCl}_{4}$ : C 56.99(57.06), H 3.99(4.47). Although these results are outside the range viewed as establishing analytical purity, they are provided to illustrate the best values obtained to date. ${ }^{1} \mathrm{H}$ NMR (acetonitrile- $d_{3}, 400 \mathrm{MHz}, 25{ }^{\circ} \mathrm{C}$, Fig. S.1) $\delta: 7.53(\mathrm{t}, 4 \mathrm{H}), 7.34(\mathrm{dt}, 4 \mathrm{H}), 7.21(\mathrm{~d}, 2 \mathrm{H}), 7.02(\mathrm{~d}, 2 \mathrm{H}), 6.95(\mathrm{~m}, 4 \mathrm{H}), 5.64\left(\mathrm{~d}, 2 \mathrm{H},{ }^{2} J_{\mathrm{PH}}\right.$ $=15.7 \mathrm{~Hz}), 5.45\left(\mathrm{dd}, 2 \mathrm{H}, J_{\mathrm{PH}}=22.6,21.0 \mathrm{~Hz}\right), 3.22(\mathrm{dqd}, 2 \mathrm{H}), 0.60\left(\mathrm{td}, 3 \mathrm{H},{ }^{4} J_{\mathrm{PH}}=1.0 \mathrm{~Hz}\right)$ ppm. ${ }^{13} \mathrm{C}\left\{{ }^{1} \mathrm{H}\right\}$ NMR (acetonitrile- $d_{3}, 126 \mathrm{MHz}, 25{ }^{\circ} \mathrm{C}$, Fig. S.2) $\delta: 140.34(\mathrm{~m}), 135.41$ (dd, $J_{\mathrm{PC}}$ $=10.2,3.2 \mathrm{~Hz}), 134.93\left(\mathrm{~d}, J_{\mathrm{PC}}=11.6 \mathrm{~Hz}\right), 132.20,130.77\left(\mathrm{~d}, J_{\mathrm{PC}}=11.5 \mathrm{~Hz}\right), 129.94\left(\mathrm{dd}, J_{\mathrm{PC}}\right.$ $=6.4,2.8 \mathrm{~Hz}), 129.70,129.63,128.81,128.57\left(\mathrm{~d}, J_{\mathrm{PC}}=4.3 \mathrm{~Hz}\right), 128.25 J_{\mathrm{PC}}=4.3 \mathrm{~Hz}, 75.15(\mathrm{~d}$, $\left.J_{\mathrm{PC}}=21.0 \mathrm{~Hz}\right), 48.82\left(\mathrm{dd}, J_{\mathrm{PC}}=7.4,2.8 \mathrm{~Hz}\right), 47.80\left(\mathrm{~d}, J_{\mathrm{PC}}=42.7 \mathrm{~Hz}\right), 15.69\left(\mathrm{~d}, J_{\mathrm{PC}}=4.0 \mathrm{~Hz}\right)$

ppm. ${ }^{27} \mathrm{Al} \mathrm{NMR}$ (acetonitrile- $d_{3}, 130 \mathrm{MHz}, 25{ }^{\circ} \mathrm{C}$, Fig. S.3) $\delta$ : 107.19 (s) ppm. ${ }^{31} \mathrm{P}\left\{{ }^{1} \mathrm{H}\right\} \mathrm{NMR}$ (acetonitrile- $d_{3}, 203 \mathrm{MHz}, 25{ }^{\circ} \mathrm{C}$, Fig. S.4) $\delta: 131.46\left(\mathrm{~d},{ }^{1} J_{\mathrm{PP}}=295 \mathrm{~Hz}, \mathrm{P}\right.$ POEt),$-94.58\left(\mathrm{~d},{ }^{1} J_{\mathrm{PP}}\right.$ $=295 \mathrm{~Hz}$, PPOEt) ppm. 


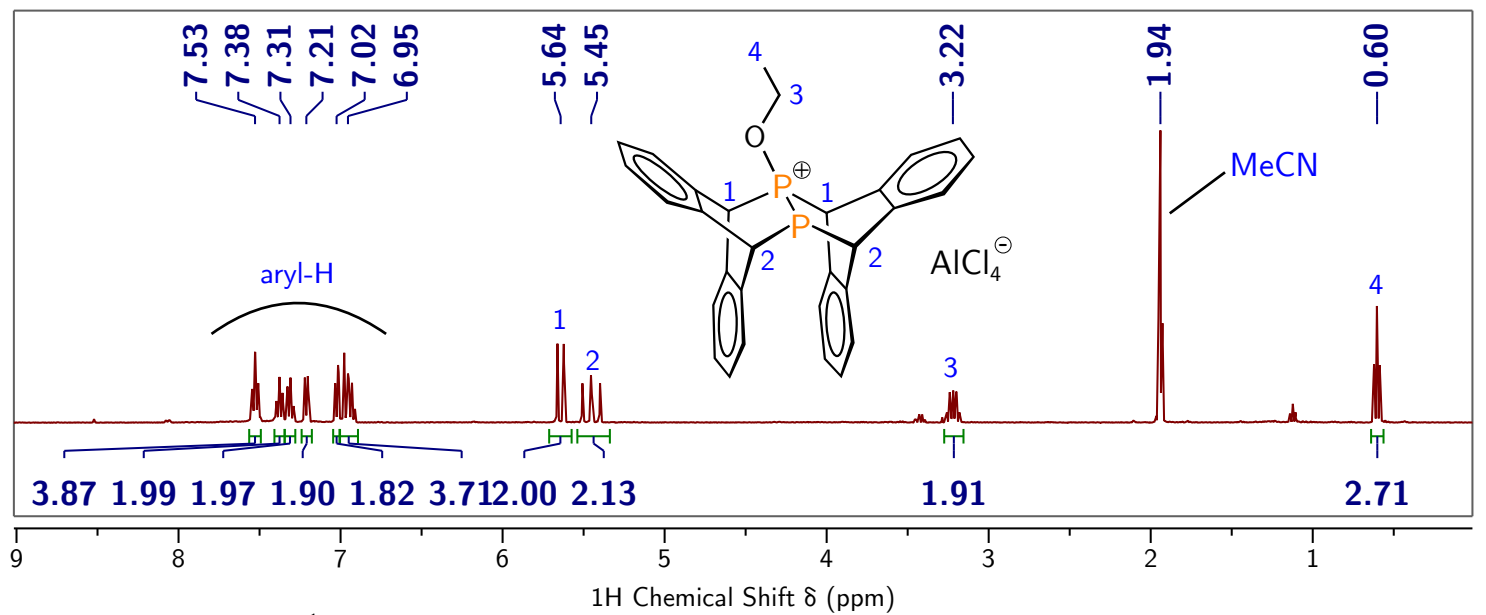

Figure S.1: ${ }^{1} \mathrm{H}$ NMR (400 MHz, acetonitrile- $\left.d_{3}, 25{ }^{\circ} \mathrm{C}\right)$ spectrum of $[\mathbf{2}] \mathrm{AlCl}_{4}$.

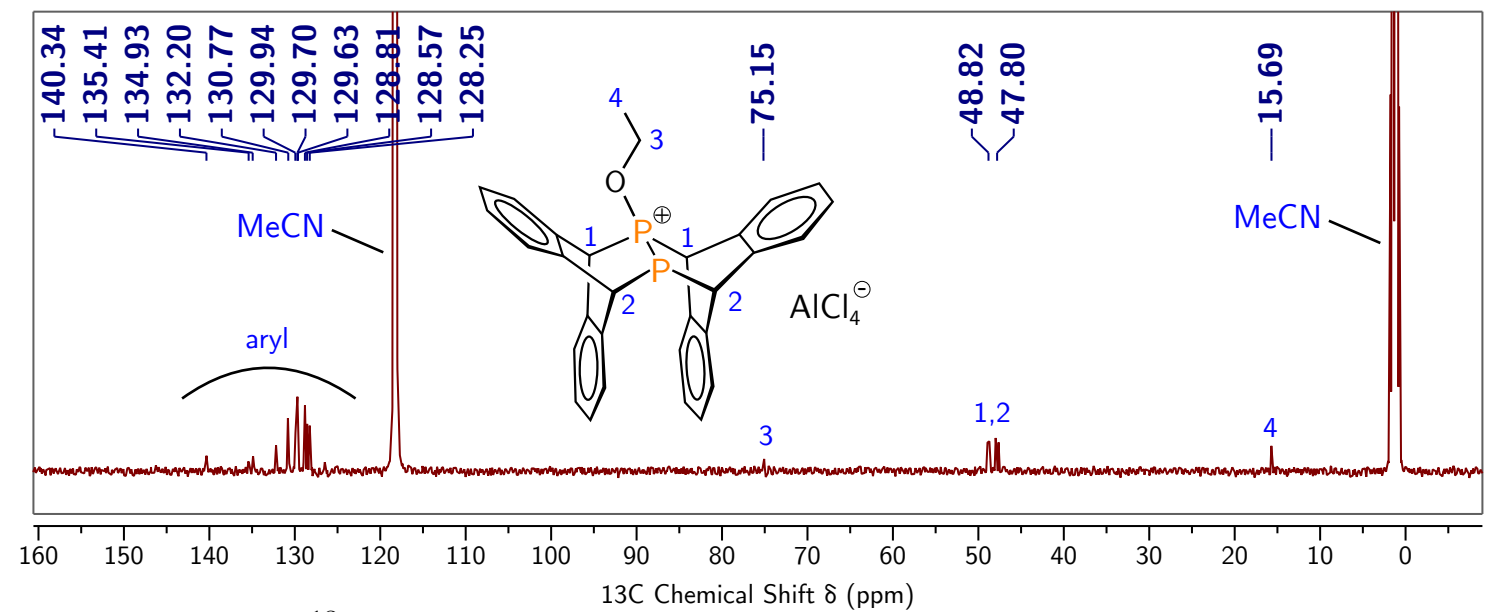

Figure S.2: ${ }^{13} \mathrm{C}$ NMR $\left(126 \mathrm{MHz}\right.$, acetonitrile- $\left.d_{3}, 25{ }^{\circ} \mathrm{C}\right)$ spectrum of $[\mathbf{2}] \mathrm{AlCl}_{4}$.

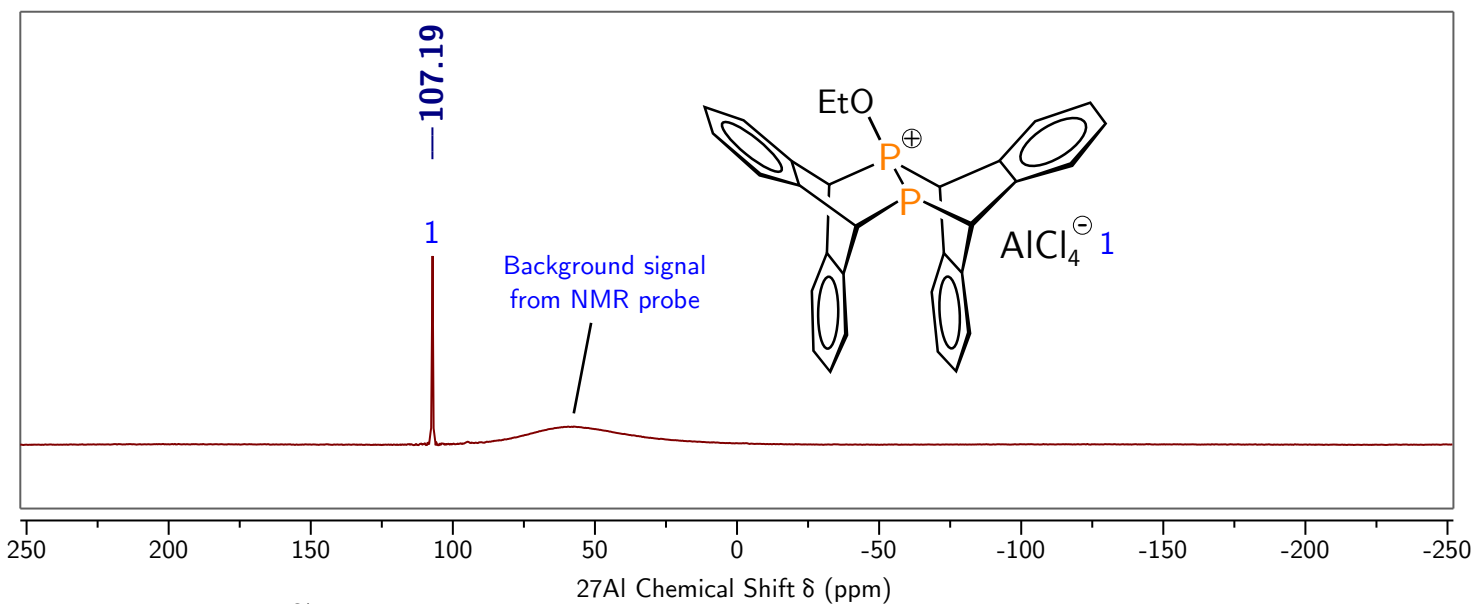

Figure S.3: ${ }^{27} \mathrm{Al}$ NMR $\left(130 \mathrm{MHz}\right.$, acetonitrile- $\left.d_{3}, 25{ }^{\circ} \mathrm{C}\right)$ spectrum of $[\mathbf{2}] \mathrm{AlCl}_{4}$. 


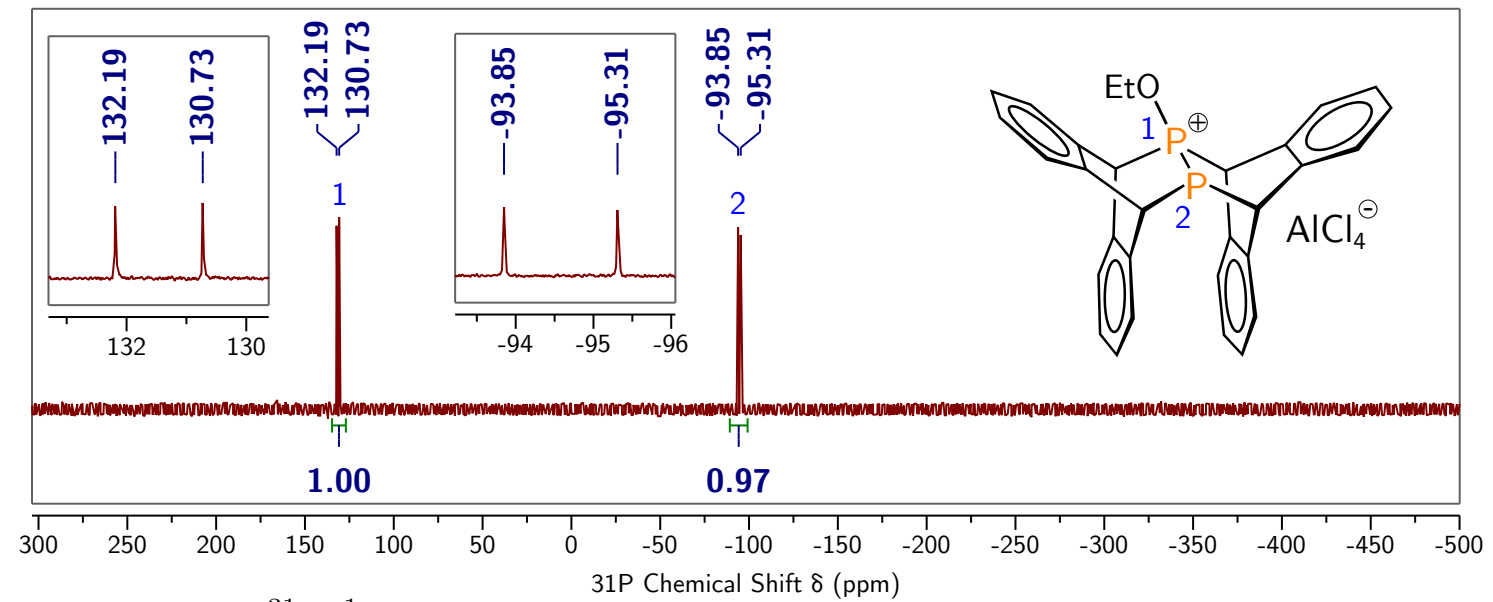

Figure S.4: ${ }^{31} \mathrm{P}\left\{{ }^{1} \mathrm{H}\right\}$ NMR $\left(203 \mathrm{MHz}\right.$, acetonitrile- $\left.d_{3}, 25{ }^{\circ} \mathrm{C}\right)$ spectrum of $[2] \mathrm{AlCl}_{4}$. 


\section{S.1.2.1 NMR Characterization of the Crude Reaction Mixture}

The ${ }^{1} \mathrm{H}$ NMR spectrum of the crude reaction mixture, $24 \mathrm{~h}$ after treating EtOPA with $\mathrm{AlCl}_{3}$ and removing volatiles under reduced pressure, is displayed in Fig. S.5. Resonances assigned to compound $[\mathbf{2}] \mathrm{AlCl}_{4}$, anthracene, and an unknown byproduct, which contains an ethoxy unit, were observed in the NMR spectrum. The resonances assigned to the unknown species do not correspond to reported oligomers of $\mathrm{EtOAlCl}_{2} \cdot[14]$

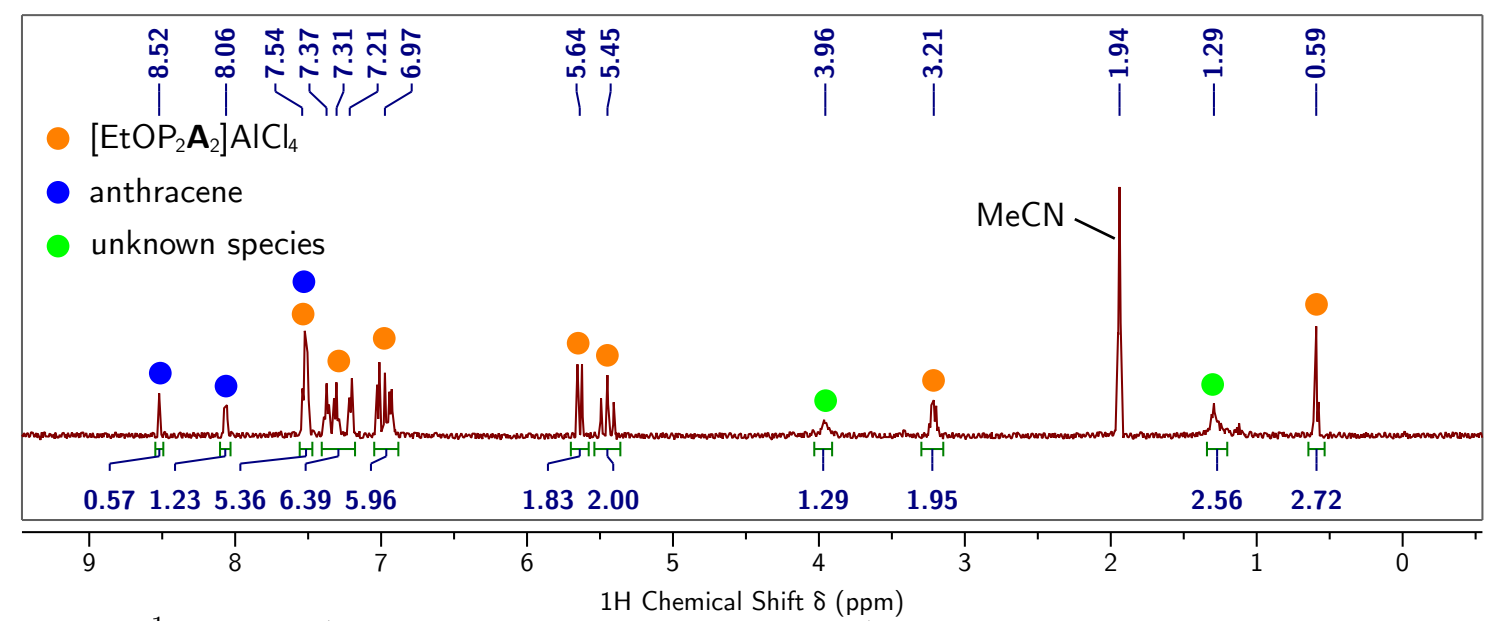

Figure S.5: ${ }^{1} \mathrm{H}$ NMR (500 MHz, acetonitrile- $\left.d_{3}, 25{ }^{\circ} \mathrm{C}\right)$ spectrum of the crude reaction mixture, $24 \mathrm{~h}$ after treating EtOPA with $\mathrm{AlCl}_{3}$ and removing volatile materials under reduced pressure. 


\section{S.1.3 Synthesis of $(\mathrm{PhPA})_{2}(3)$}

A $1 \mathrm{M}$ THF solution of phenylmagnesium chloride $(2.36 \mathrm{~mL}, 2.36 \mathrm{mmol}, 2.00$ equiv) was added dropwise to a thawing solution of $[2] \mathrm{AlCl}_{4}(750 \mathrm{mg}, 1.18 \mathrm{mmol}, 1.00$ equiv) in THF (25 mL). The mixture was stirred as it warmed to $23{ }^{\circ} \mathrm{C}$ over $1 \mathrm{~h}$. All volatile materials were removed from the solution under reduced pressure, resulting in a colorless residue. The residue was taken up in benzene $(10 \mathrm{~mL})$ and filtered through a coarse sintered frit $(15 \mathrm{~mL})$ containing a two inch plug of basic alumina at a rate of $1 \mathrm{~mL} / \mathrm{min}$. The plug was washed with additional benzene $(5 \mathrm{~mL})$ and all volatile materials were removed from the combined filtrates in vacuo, providing $\mathbf{3}$ as a white solid (400 mg, $0.698 \mathrm{mmol}, 59 \%$ ). Elem. Anal. Calc'd(found) for $\mathrm{C}_{40} \mathrm{H}_{30} \mathrm{P}_{2}$ : C 83.90(84.03), H 5.28(5.41). ${ }^{1} \mathrm{H}$ NMR (benzene- $d_{6}, 500 \mathrm{MHz}, 25{ }^{\circ} \mathrm{C}$, Fig. S.6) $\delta: 7.82(\mathrm{~m}, 4 \mathrm{H}), 7.22(\mathrm{~m}, 6 \mathrm{H}), 6.99$ $(\mathrm{m}, 4 \mathrm{H}), 6.89(\mathrm{~m}, 4 \mathrm{H}), 6.84(\mathrm{~m}, 4 \mathrm{H}), 6.77(\mathrm{~m}, 4 \mathrm{H}), 4.82\left(\mathrm{~d}, 4 \mathrm{H},{ }^{2} J_{\mathrm{PH}}=1.8 \mathrm{~Hz}\right) \mathrm{ppm} .{ }^{13} \mathrm{C}\left\{{ }^{1} \mathrm{H}\right\}$ NMR (chloroform- $d, 126 \mathrm{MHz}, 25{ }^{\circ} \mathrm{C}$, Fig. S.7) $\delta: 141.95$ (t, J = 12.9 Hz), 134.47, $134.40\left(\mathrm{t},{ }^{2} J_{\mathrm{PC}}\right.$ $=11.8 \mathrm{~Hz}) 129.29,128.97\left(\mathrm{t},{ }^{1} J_{\mathrm{PC}}=3.6 \mathrm{~Hz}\right), 128.89,127.09,126.85,126.17,125.50,52.49(\mathrm{~m})$ ppm. ${ }^{31} \mathrm{P}\left\{{ }^{1} \mathrm{H}\right\}$ NMR (chloroform-d, $203 \mathrm{MHz}, 25{ }^{\circ} \mathrm{C}$, Fig. S.8) $\delta$ : -1.23 (s) ppm.

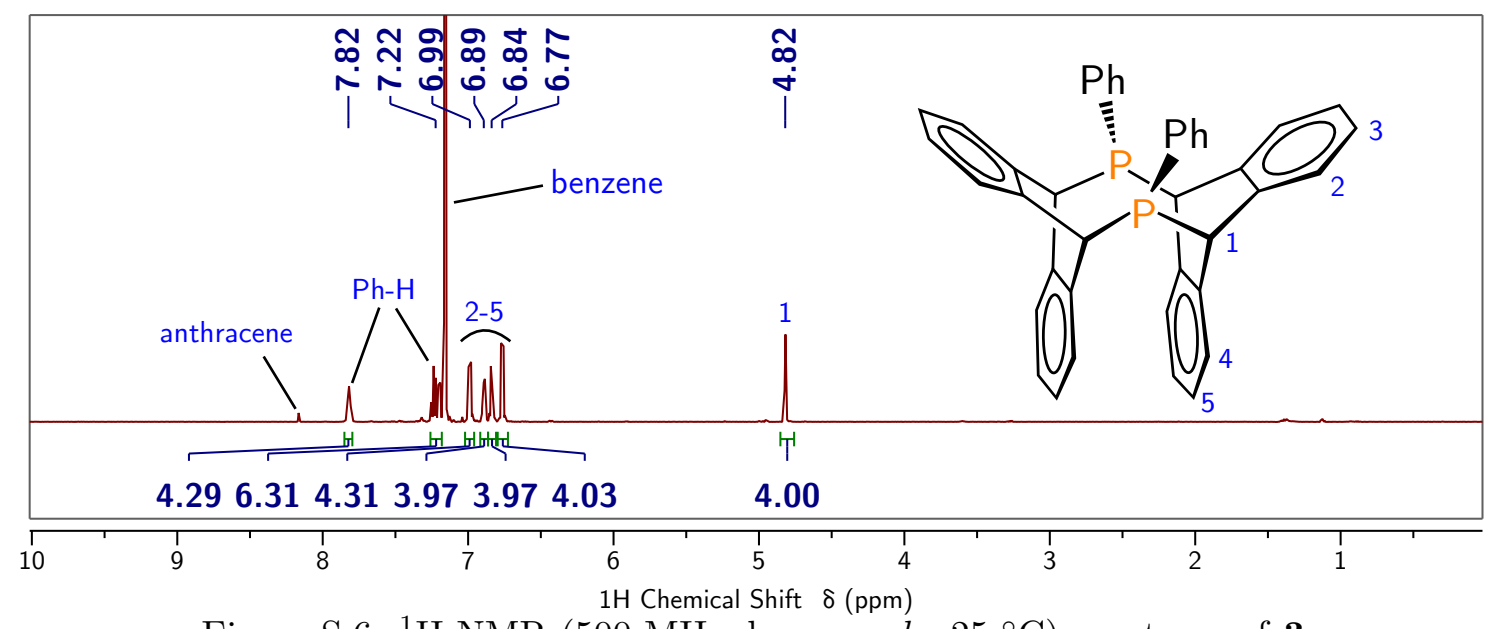

Figure S.6: ${ }^{1} \mathrm{H}$ NMR $\left(500 \mathrm{MHz}\right.$, benzene- $\left.d_{6}, 25^{\circ} \mathrm{C}\right)$ spectrum of 3. 


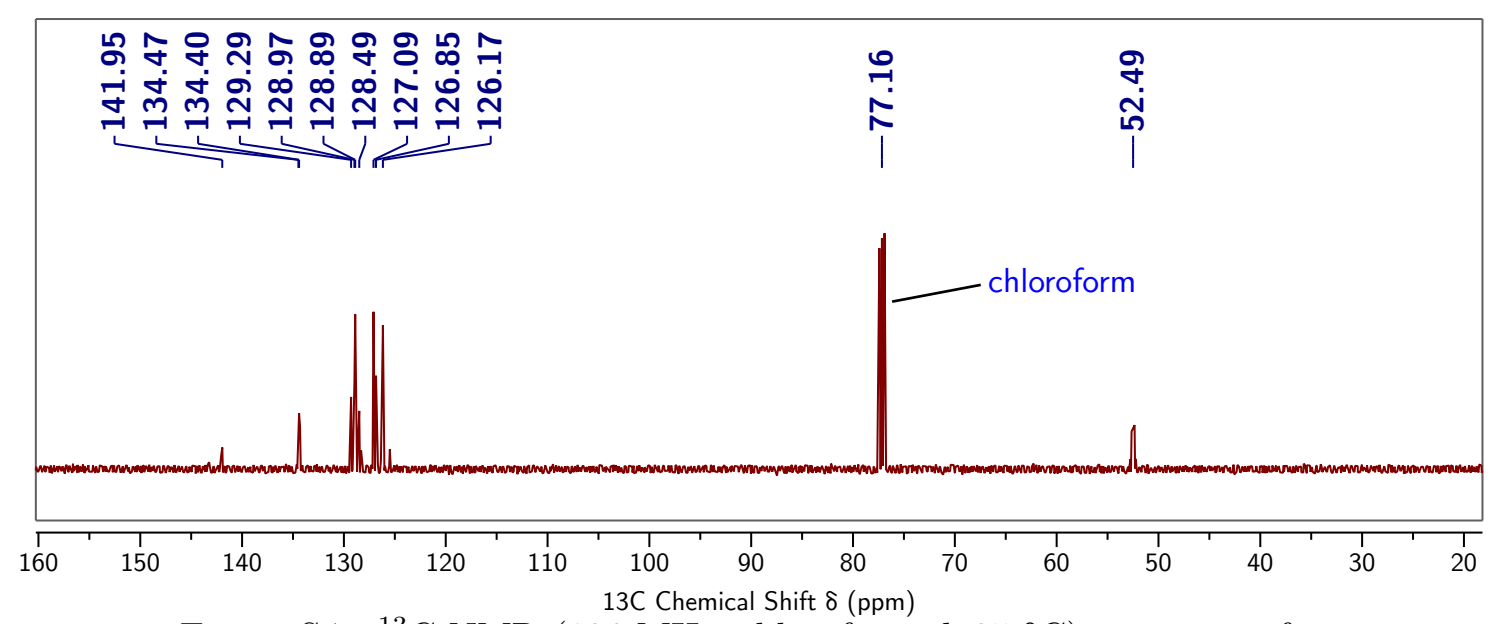

Figure S.7: ${ }^{13} \mathrm{C}$ NMR $\left(126 \mathrm{MHz}\right.$, chloroform- $\left.d, 25{ }^{\circ} \mathrm{C}\right)$ spectrum of 3.

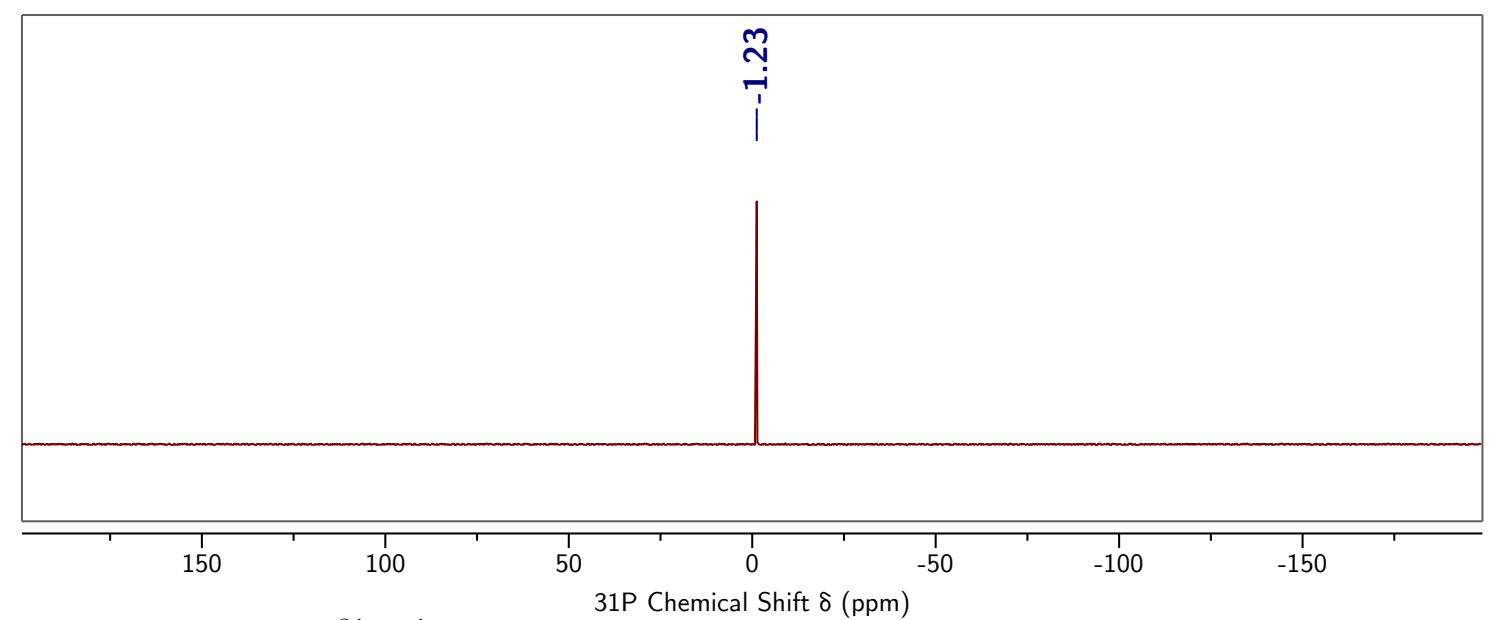

Figure S.8: ${ }^{31} \mathrm{P}\left\{{ }^{1} \mathrm{H}\right\}$ NMR (203 MHz, chloroform- $\left.d, 25{ }^{\circ} \mathrm{C}\right)$ spectrum of 3 . 


\section{S.1.4 Synthesis of $\left[(\mathrm{PhPA})_{2}\right] \mathrm{NiCl}_{2}(4)$ in Dichloromethane}

(DME) $\mathrm{NiCl}_{2}$ (83 mg, $0.38 \mathrm{mmol}, 1.0$ equiv) was added portion wise to a stirring solution of 3 (215 mg, $0.375 \mathrm{mmol}, 1.0$ equiv) in dichloromethane (4 mL). The mixture was stirred for $24 \mathrm{~h}$, during which time significant amounts of purple precipitate formed. The solids were collected on a medium sintered frit $(15 \mathrm{~mL})$ by vacuum filtration and were washed with $-35{ }^{\circ} \mathrm{C}$ dichloromethane $(2 \times 1.5 \mathrm{~mL})$, providing 4 as a purple solid $(236 \mathrm{mg}, 0.34 \mathrm{mmol}, 89 \%)$. ${ }^{1} \mathrm{H}$ NMR (dichloromethane$d_{2}, 500 \mathrm{MHz}, 25^{\circ} \mathrm{C}$, Fig. S.9) $\delta: 8.16(\mathrm{br}, 4 \mathrm{H}), 7.64(\mathrm{~m}, 6 \mathrm{H}), 7.38(\mathrm{dd}, J=5.5,3.3 \mathrm{~Hz}, 4 \mathrm{H}), 7.14(\mathrm{dd}$, $J=5.0,3.7 \mathrm{~Hz}, 4 \mathrm{H}), 6.92(\mathrm{dd}, J=5.5,3.3 \mathrm{~Hz}, 4 \mathrm{H}), 6.87(\mathrm{dd}, J=5.4,3.7 \mathrm{~Hz}, 4 \mathrm{H}), 4.73(\mathrm{br}, 4 \mathrm{H})$ ppm. ${ }^{13} \mathrm{C}\left\{{ }^{1} \mathrm{H}\right\}$ NMR (dichloromethane- $d_{2}, 126 \mathrm{MHz}, 25{ }^{\circ} \mathrm{C}$, Fig. S.10) $\delta: 139.08,135.72,134.96$, 131.82, 130.20, 128.99, 128.87, 128.46, $55.31 \mathrm{ppm} .{ }^{31} \mathrm{P}\left\{{ }^{1} \mathrm{H}\right\}$ NMR (dichloromethane- $d_{2}, 203 \mathrm{MHz}$, $25{ }^{\circ} \mathrm{C}$, Fig. S.11) $\delta:-12.02(\mathrm{~s}) \mathrm{ppm}$.

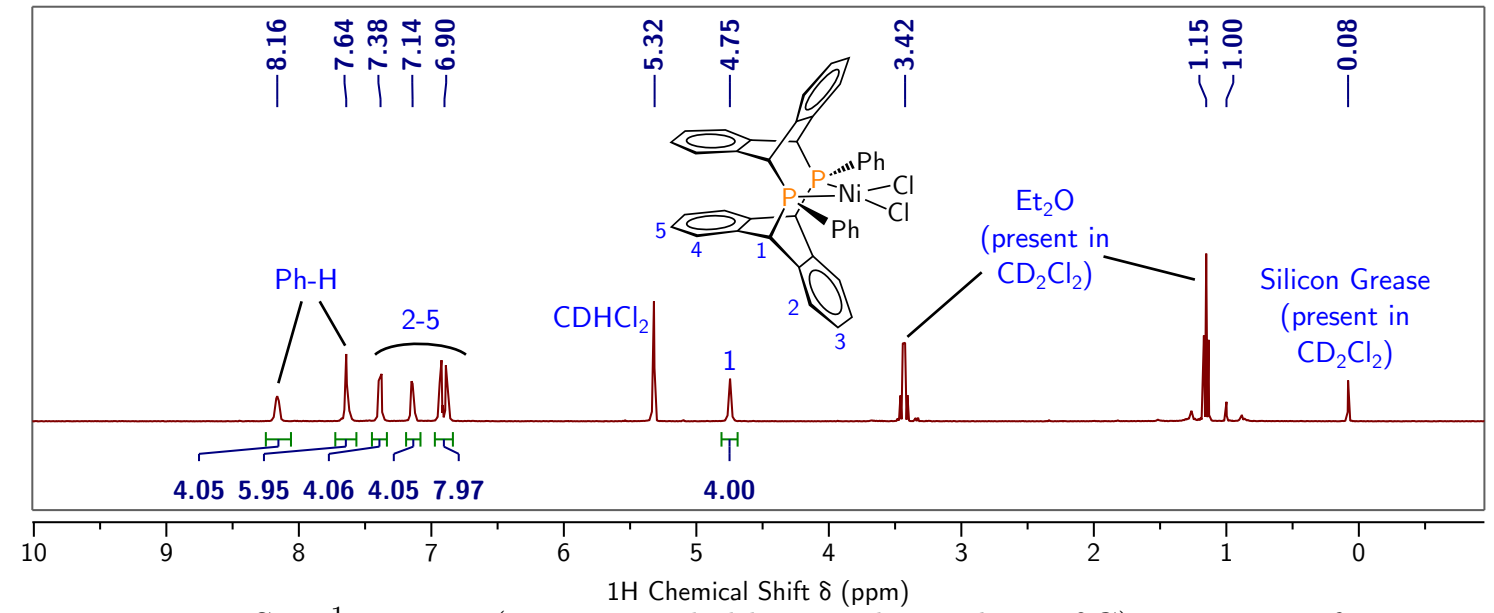

Figure S.9: ${ }^{1} \mathrm{H}$ NMR (500 MHz, dichloromethane- $\left.d_{2}, 25{ }^{\circ} \mathrm{C}\right)$ spectrum of 4.

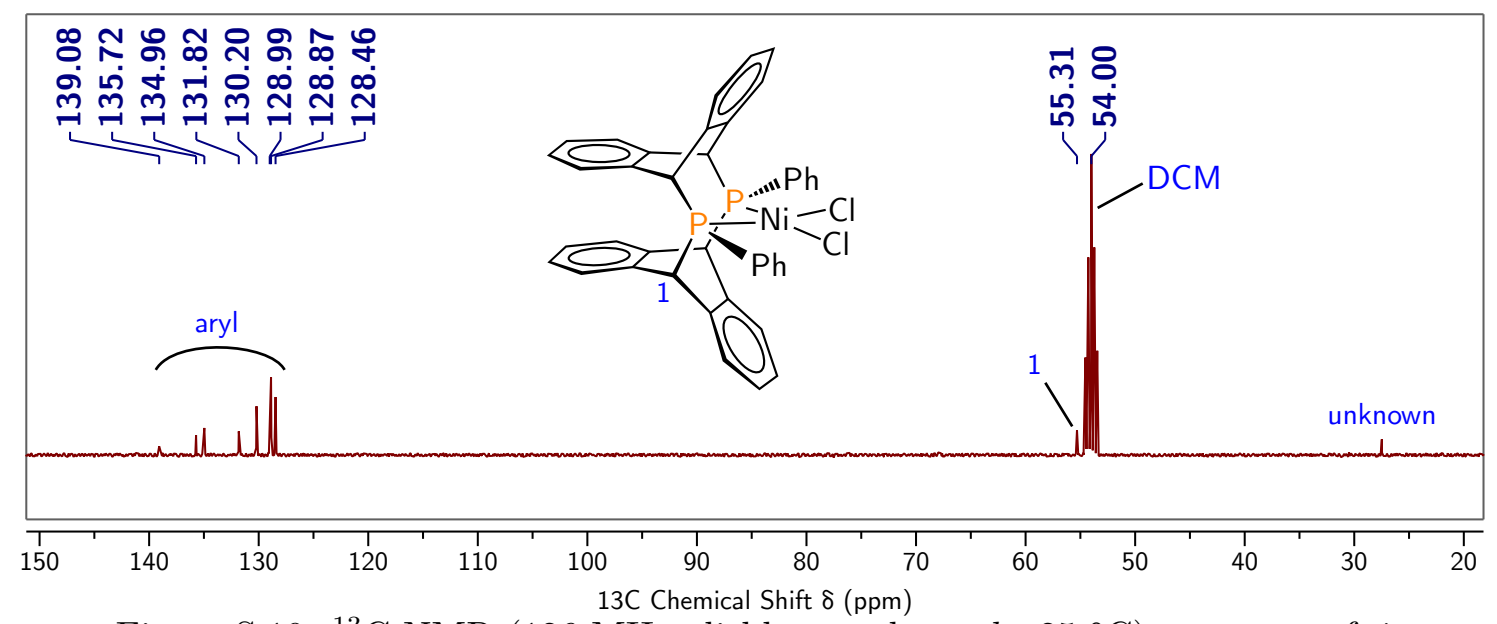

Figure S.10: ${ }^{13} \mathrm{C}$ NMR $\left(126 \mathrm{MHz}\right.$, dichloromethane- $\left.d_{2}, 25{ }^{\circ} \mathrm{C}\right)$ spectrum of 4. 


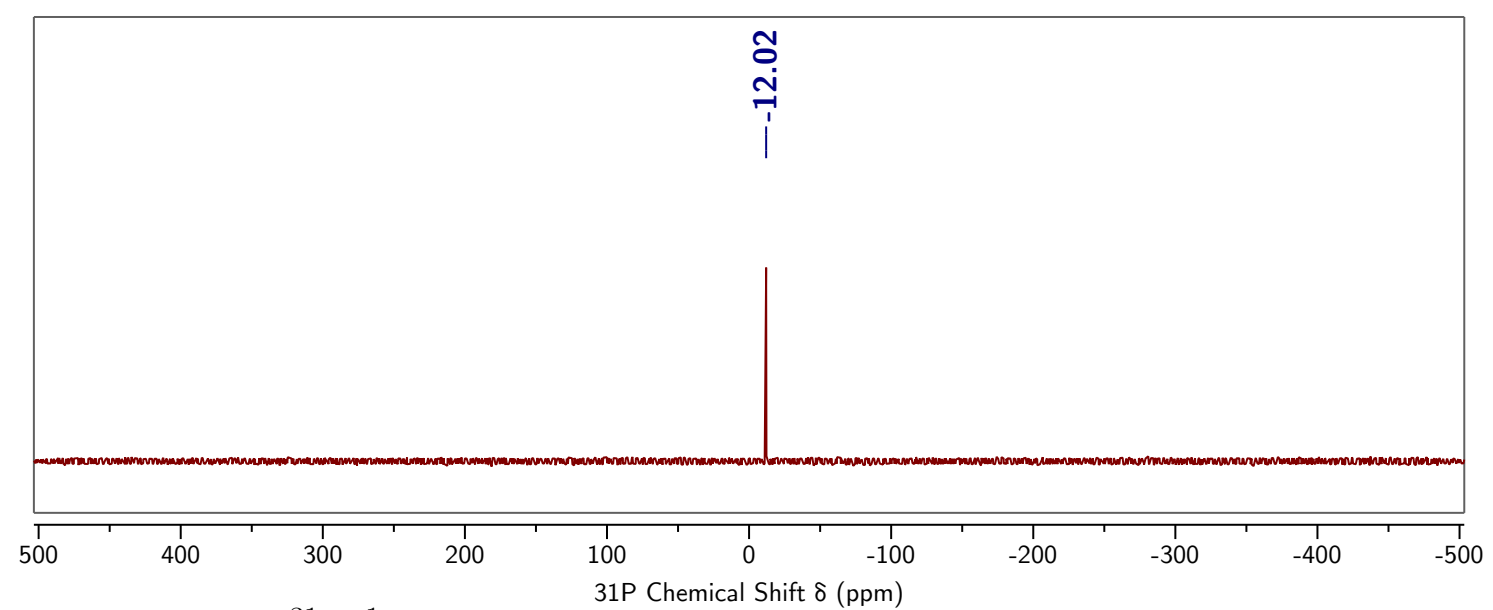

Figure S.11: ${ }^{31} \mathrm{P}\left\{{ }^{1} \mathrm{H}\right\} \mathrm{NMR}\left(203 \mathrm{MHz}\right.$, dichloromethane- $d_{2}, 25{ }^{\circ} \mathrm{C}$ ) spectrum of 4.

\section{S.1.4.1 NMR Characterization of the Filtrate}

All volatile materials were removed from the filtrate, obtained from the reaction described in section S.1.4, under reduced pressure. ${ }^{1} \mathrm{H}$ and ${ }^{31} \mathrm{P}$ NMR spectra of the resulting brown residue in dichloromethane- $d_{2}$ are displayed in Fig. S.12 and Fig. S.13, respectively. Resonances assigned to complex 4, anthracene, and unknown byproducts are present in the ${ }^{1} \mathrm{H}$ NMR spectrum. Resonances assigned to complex 4 and unknown phosphorus-containing byproducts are present in the ${ }^{31} \mathrm{P}\left\{{ }^{1} \mathrm{H}\right\}$ NMR spectrum. These observations are consistent with partial decomposition of ligand $\mathbf{3}$ during the reaction described in section S.1.4.

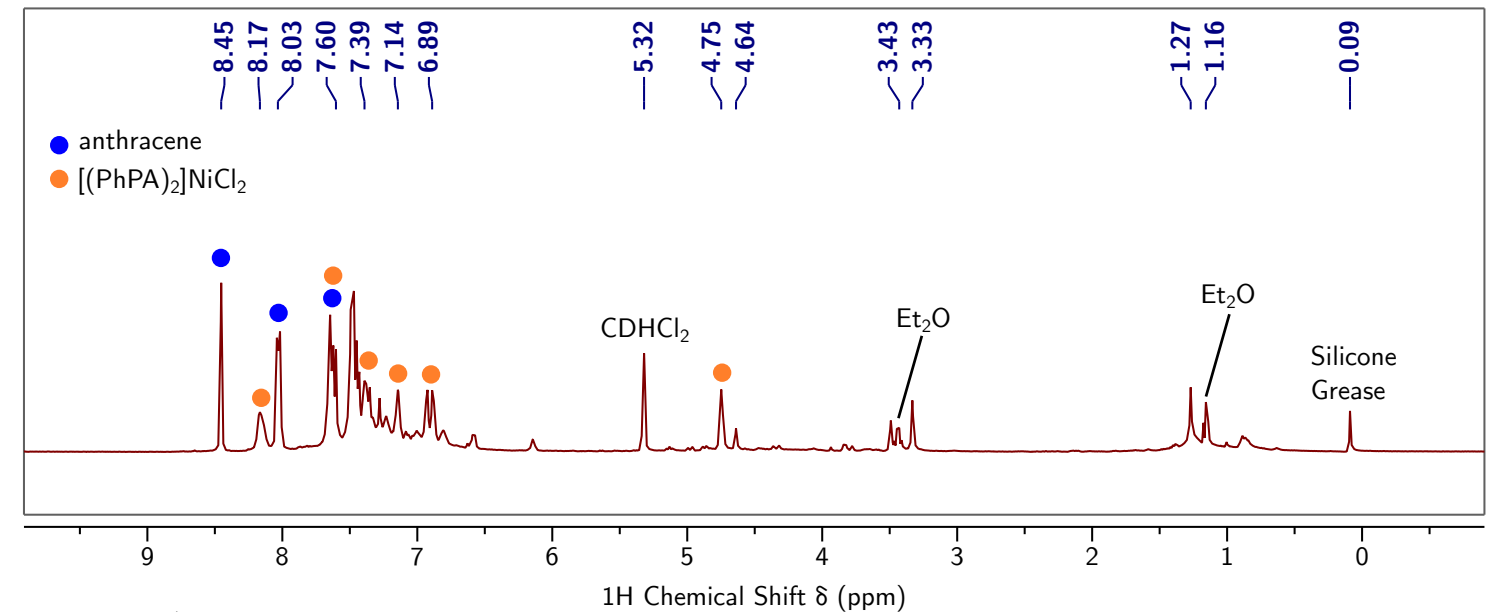

Figure S.12: ${ }^{1} \mathrm{H}$ NMR (400 MHz, dichloromethane- $d_{2}, 25{ }^{\circ} \mathrm{C}$ ) spectrum of the filtrate, $24 \mathrm{~h}$ after treating (DME) $\mathrm{NiCl}_{2}$ with ligand 3. 


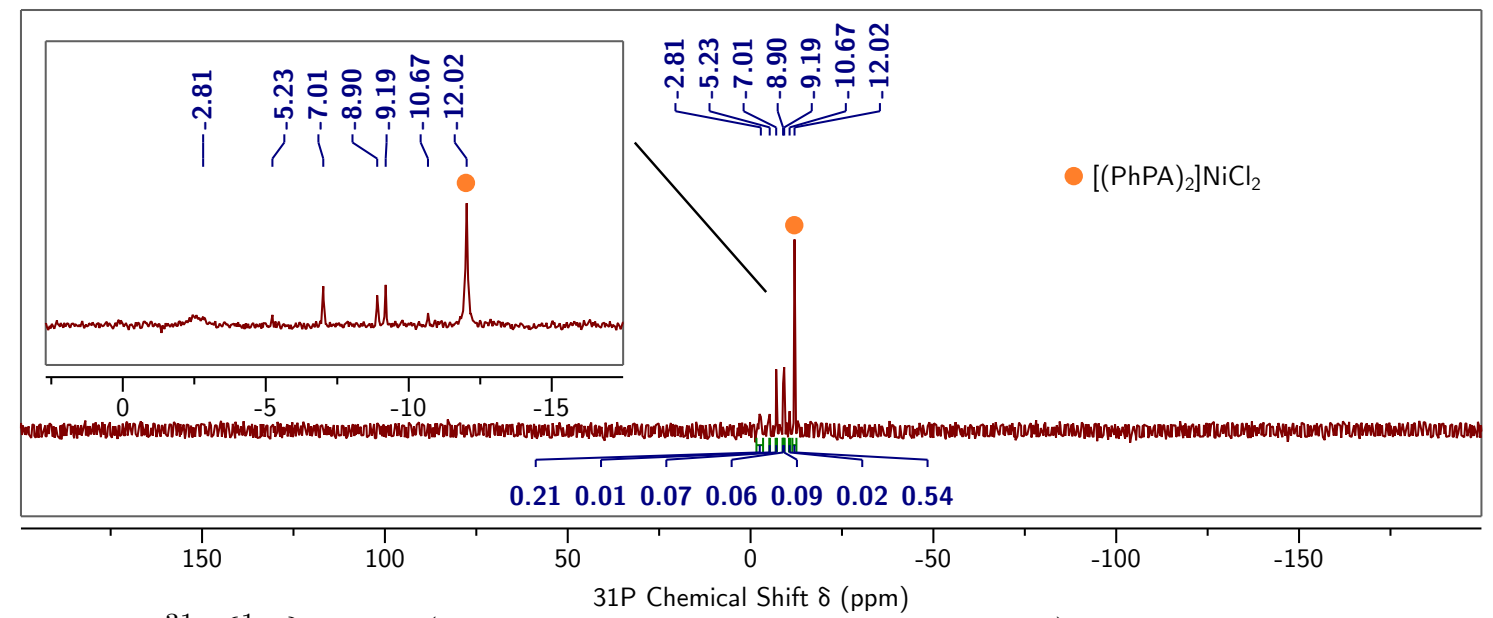

Figure S.13: ${ }^{31} \mathrm{P}\left\{{ }^{1} \mathrm{H}\right\}$ NMR (162 MHz, dichloromethane- $\left.d_{2}, 25{ }^{\circ} \mathrm{C}\right)$ spectrum of the filtrate, $24 \mathrm{~h}$ after treating $(\mathrm{DME}) \mathrm{NiCl}_{2}$ with ligand $\mathbf{3}$.

\section{S.1.4.2 Stability of 4 in Solution}

A $c a$. $0.005 \mathrm{M}$ dichloromethane- $d_{2}$ solution complex 4 was prepared. No decomposition of the complex was observed after $24 \mathrm{~h}$ at $23{ }^{\circ} \mathrm{C}$, as assessed by ${ }^{1} \mathrm{H}$ NMR and ${ }^{31} \mathrm{P}\left\{{ }^{1} \mathrm{H}\right\} \mathrm{NMR}$ spectroscopy.

\section{S.1.4.3 Space-Filling Diagrams of 4}

Coordinates of complex 4 were obtained from a single X-ray diffraction experiment (S.2). Space filling diagrams of 4 were generated using Avogadro [29] and are depicted in Fig. S.14.
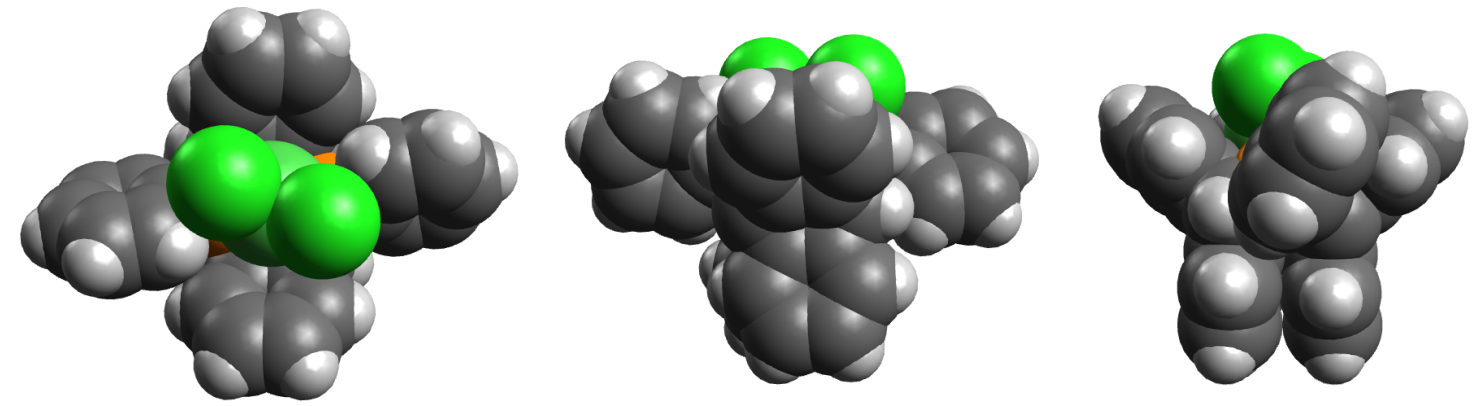

Figure S.14: Space filling diagrams of 4. P (orange), Ni (green), Cl (lime green), C (gray), H (white). 


\section{S.1.5 Synthesis of $\left\{\left[(\mathrm{PhPA})_{2}\right] \mathrm{NiCl}\right\}_{2}\left[\mathrm{~B}\left(\mathrm{C}_{6} \mathbf{F}_{5}\right)_{4}\right]_{2}(5)$}

To a rapidly stirring slurry of $4(75 \mathrm{mg}, 0.11 \mathrm{mmol}, 1.0$ equiv) in dichloromethane $(3 \mathrm{~mL})$ was added $\mathrm{K}\left[\mathrm{B}\left(\mathrm{C}_{6} \mathrm{~F}_{5}\right)_{4}\right]$ (96 mg, $0.11 \mathrm{mmol}, 1.0$ equiv). After $30 \mathrm{~min}$, the initially purple solution became bright red. All volatile materials were removed in vacuo, resulting in a red residue. Orthodifluorobenzene $(3 \mathrm{~mL})$ was added to the residue and the resulting heterogeneous mixture was filtered through a glass fiber filter paper plugged pipette containing one inch of diatomaceous earth. The plug was washed with ortho-difluorobenzene $(1 \mathrm{~mL})$ and the combined filtrates were concentrated to ca. $2 \mathrm{~mL}$. The saturated solution was then placed in a $-35{ }^{\circ} \mathrm{C}$ freezer for $72 \mathrm{~h}$, during which time red crystals of $\mathbf{5}$ formed. The supernatant was decanted from the crystals and the crystals were washed with a minimal amount of cold $\left(-35{ }^{\circ} \mathrm{C}\right)$ ortho-difluorobenzene. The crystals were dried to constant mass under reduced pressure (63 mg, $0.023 \mathrm{mmol}, 43 \%$ ). Elem. Anal. Calc'd(found) for $\mathrm{C}_{128} \mathrm{H}_{60} \mathrm{~F}_{40} \mathrm{Cl}_{2} \mathrm{~B}_{2} \mathrm{P}_{4} \mathrm{Ni}_{2}$ : C 57.12(56.27), H 2.25(2.53). Although these results are outside the range viewed as establishing analytical purity, they are provided to illustrate the best values obtained to date. ${ }^{1} \mathrm{H}$ NMR (ortho-dichlorobenzene- $d_{4}, 500 \mathrm{MHz}, 25{ }^{\circ} \mathrm{C}, \mathrm{Fig}$. S.15) $\delta: 7.76,7.68,7.59,7.46,7.10,7.00,5.04$ ppm. ${ }^{11} \mathrm{~B}$ NMR (ortho-dichlorobenzene- $d_{4}, 128 \mathrm{MHz}, 25$ ${ }^{\circ} \mathrm{C}$, Fig. S.16) $\delta-16.07$ ppm. ${ }^{19} \mathrm{~F}$ NMR (ortho-dichlorobenzene- $d_{4}, 471 \mathrm{MHz}, 25{ }^{\circ} \mathrm{C}$, Fig. S.17) $\delta-131.54,-162.10,-165.89$ ppm. ${ }^{31} \mathrm{P}\left\{{ }^{1} \mathrm{H}\right\}$ NMR (ortho-dichlorobenzene- $d_{4}, 203 \mathrm{MHz}, 25{ }^{\circ} \mathrm{C}$, Fig. S.18) $\delta$ : $-13.00(\mathrm{~s}) \mathrm{ppm}$.

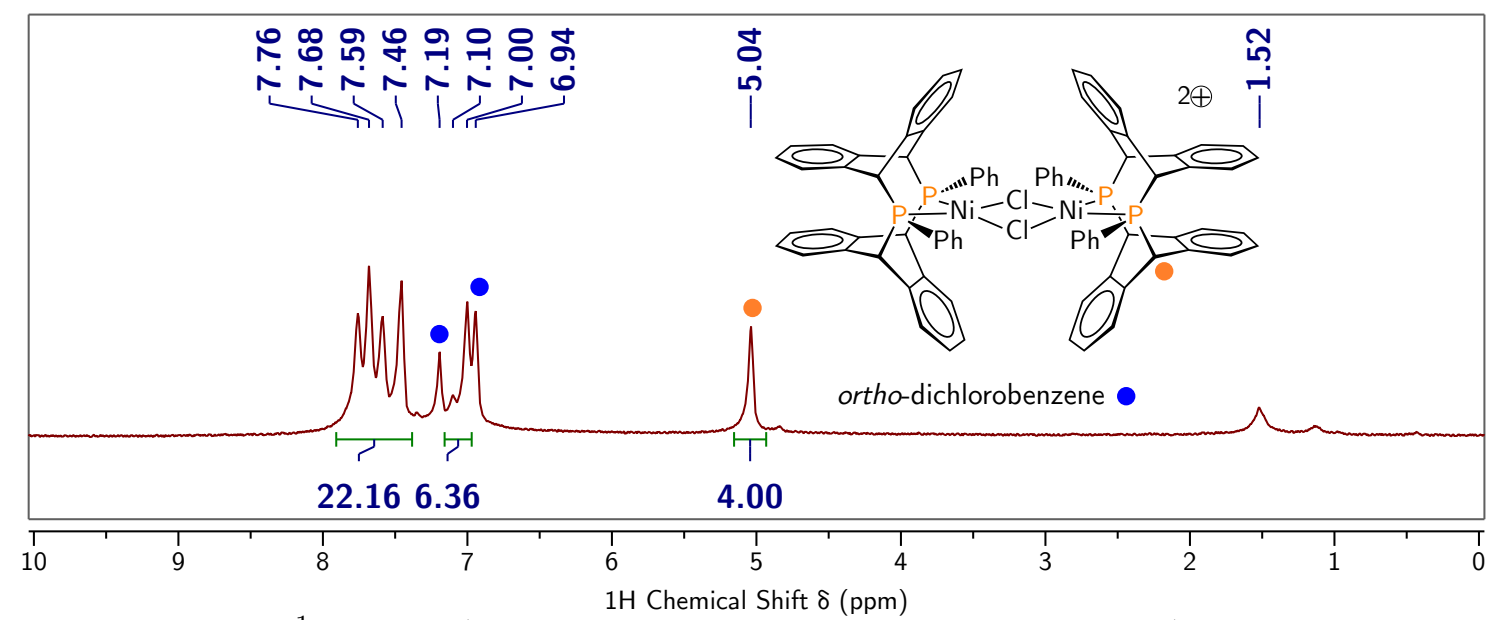

Figure S.15: ${ }^{1} \mathrm{H}$ NMR (500 MHz, ortho-dichlorobenzene- $\left.d_{4}, 25{ }^{\circ} \mathrm{C}\right)$ spectrum of 5 . 


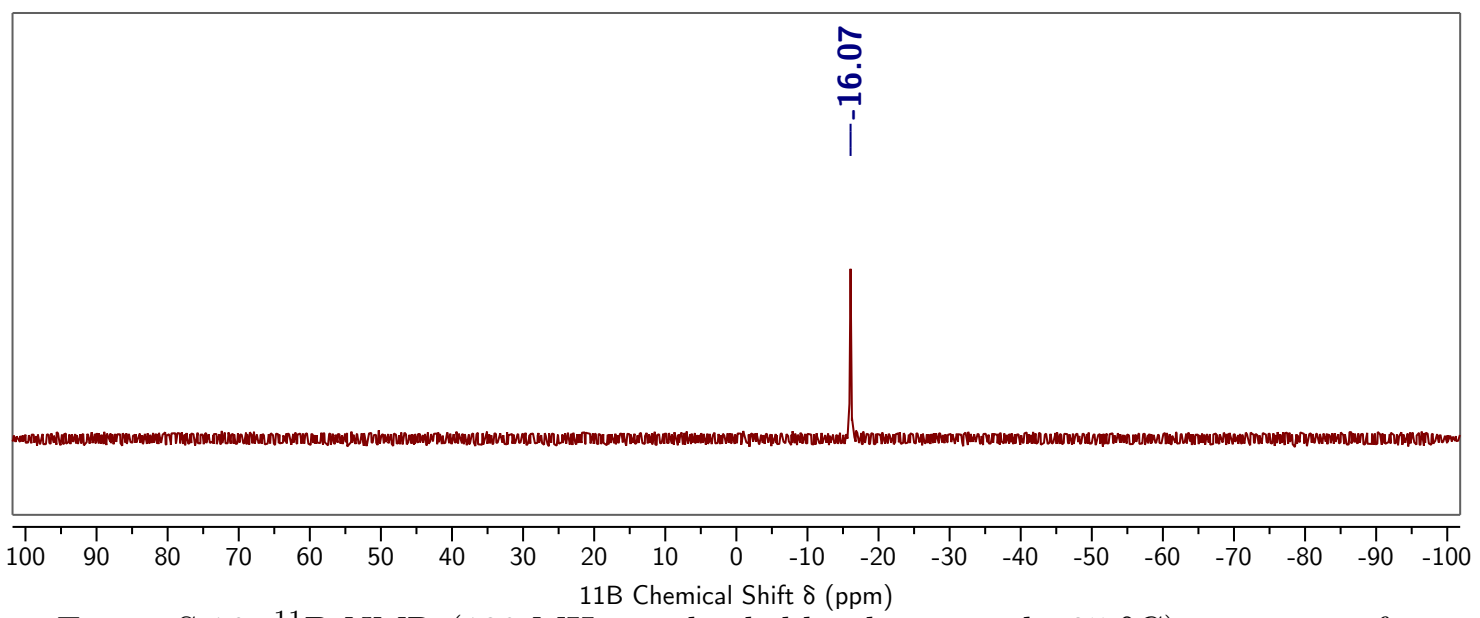

Figure S.16: ${ }^{11} \mathrm{~B}$ NMR $\left(128 \mathrm{MHz}\right.$, ortho-dichlorobenzene- $\left.d_{4}, 25{ }^{\circ} \mathrm{C}\right)$ spectrum of 5 .

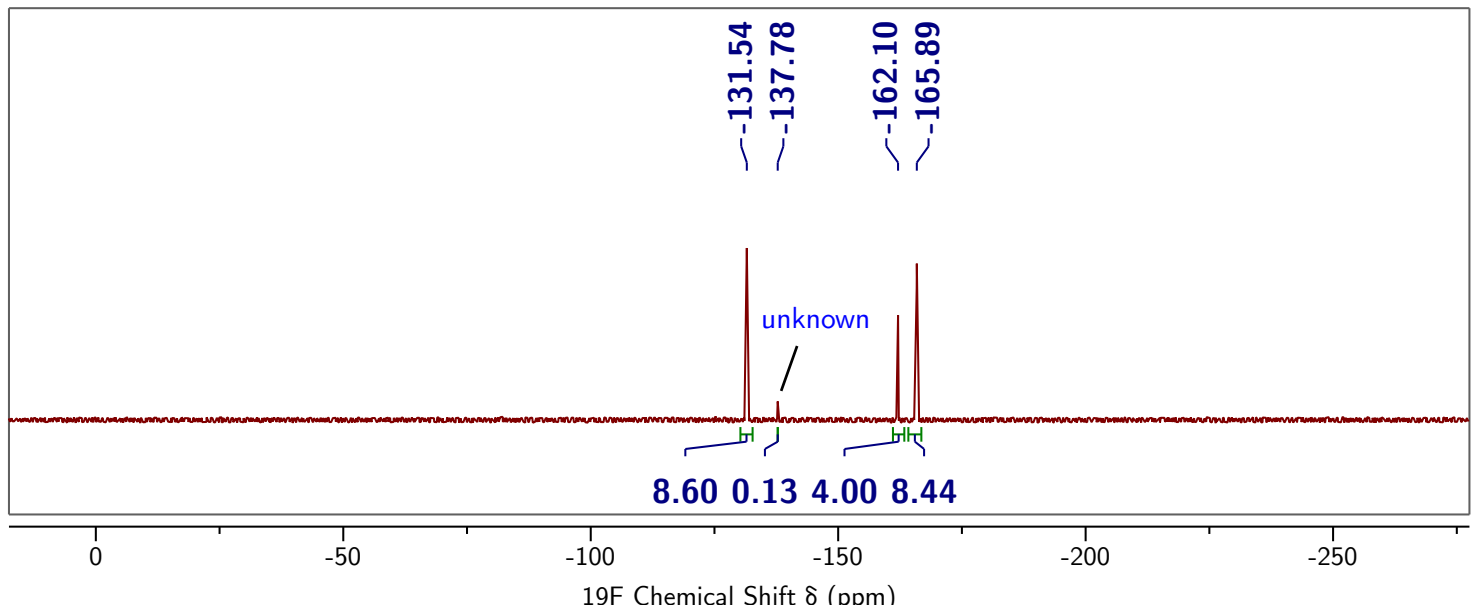

Figure S.17: ${ }^{19} \mathrm{~F}$ NMR (471 MHz, ortho-dichlorobenzene- $\left.d_{4}, 25{ }^{\circ} \mathrm{C}\right)$ spectrum of $\mathbf{5}$.

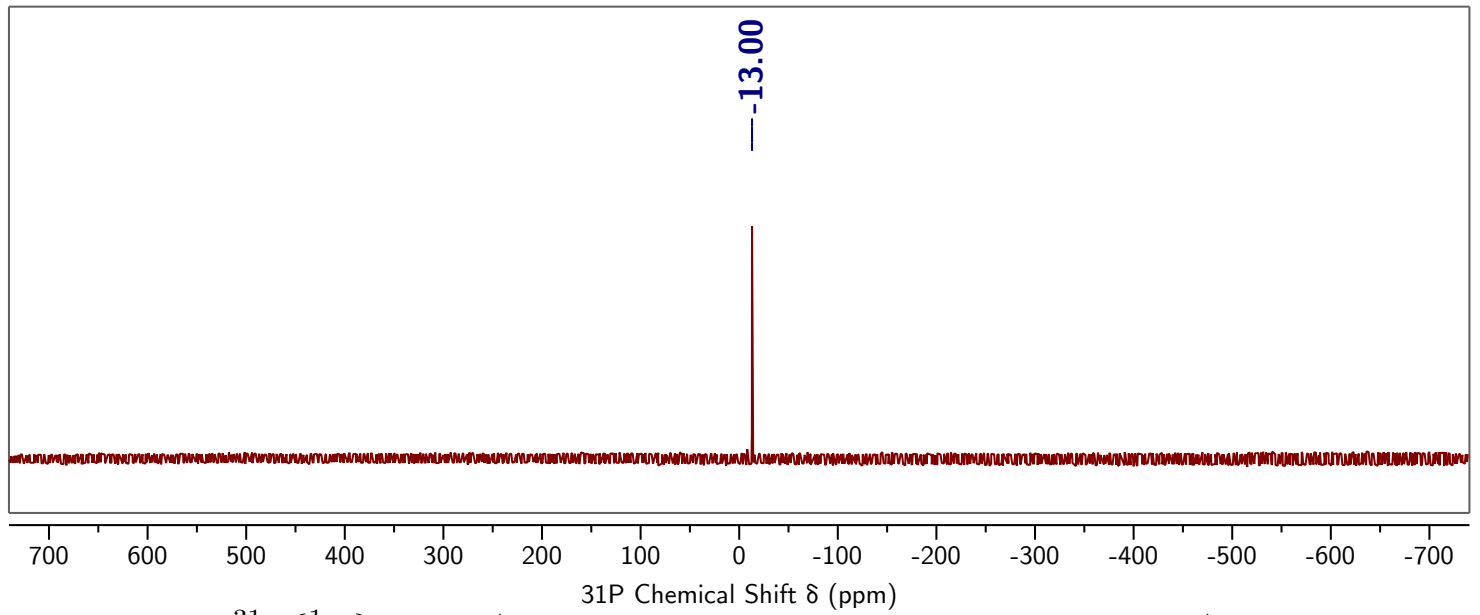

Figure S.18: ${ }^{31} \mathrm{P}\left\{{ }^{1} \mathrm{H}\right\}$ NMR $\left(203 \mathrm{MHz}\right.$, ortho-dichlorobenzene- $\left.d_{4}, 25{ }^{\circ} \mathrm{C}\right)$ spectrum of $\mathbf{5}$. 


\section{S.1.5.1 Treatment of 5 with Acetonitrile}

A purple homogeneous solution was obtained when compound 5 (5 mg) was dissolved in acetonitrile$d_{3}(0.7 \mathrm{~mL})$. Two broad bridgehead signals were observed at $5.18\left(\Delta \nu_{1 / 2}=38 \mathrm{~Hz}\right)$ and $4.89\left(\Delta \nu_{1 / 2}=\right.$ $34 \mathrm{~Hz}$ ) ppm in the ${ }^{1} \mathrm{H}$ NMR spectrum (Fig. S.19) and two broad signals centered at -11.97 $\left(\Delta \nu_{1 / 2}=119 \mathrm{~Hz}\right)$ and $-14.87\left(\Delta \nu_{1 / 2}=155 \mathrm{~Hz}\right)$ ppm were observed in the ${ }^{31} \mathrm{P}\left\{{ }^{1} \mathrm{H}\right\} \mathrm{NMR}$ spectrum (Fig. S.20). These signals are consistent with cleavage of the dimer and association of acetonitrile$d_{3}$ to the cationic nickel centers. Removal of acetonitrile- $d_{3}$ under reduced pressure resulted in a red residue. ${ }^{1} \mathrm{H}$ NMR and ${ }^{31} \mathrm{P}\left\{{ }^{1} \mathrm{H}\right\}$ NMR spectra of the red residue in ortho-dichlorobenzene- $d_{4}$ match spectra of complex 5 depicted in S.1.5. ${ }^{1} \mathrm{H}$ NMR (acetonitrile- $d_{3}, 500 \mathrm{MHz}, 25{ }^{\circ} \mathrm{C}$, Fig. S.19) $\delta: 8.20(4 \mathrm{H}, \mathrm{br}), 7.72(6 \mathrm{H}, \mathrm{br}), 7.40(6 \mathrm{H}, \mathrm{br}), 7.18(5 \mathrm{H}, \mathrm{br}), 6.94(6 \mathrm{H}, \mathrm{br}) 5.18(2 \mathrm{H}, \mathrm{br}), 4.89(2 \mathrm{H}$, br) ppm. ${ }^{31} \mathrm{P}\left\{{ }^{1} \mathrm{H}\right\}$ NMR (acetonitrile- $d_{3}, 203 \mathrm{MHz}, 25{ }^{\circ} \mathrm{C}$, Fig. S.20) $\delta$ : -11.97 (br) and -14.87 (br) ppm.

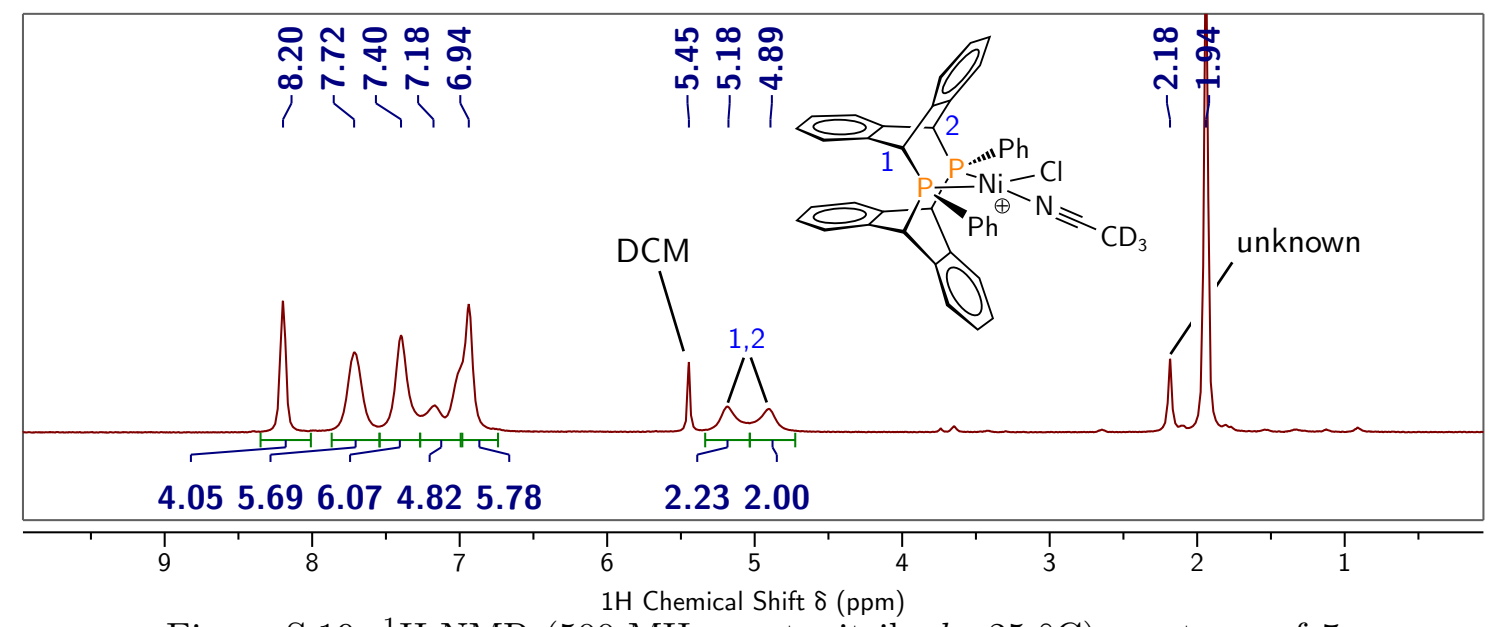

Figure S.19: ${ }^{1} \mathrm{H}$ NMR $\left(500 \mathrm{MHz}\right.$, acetonitrile- $\left.d_{3}, 25{ }^{\circ} \mathrm{C}\right)$ spectrum of $\mathbf{5}$. 


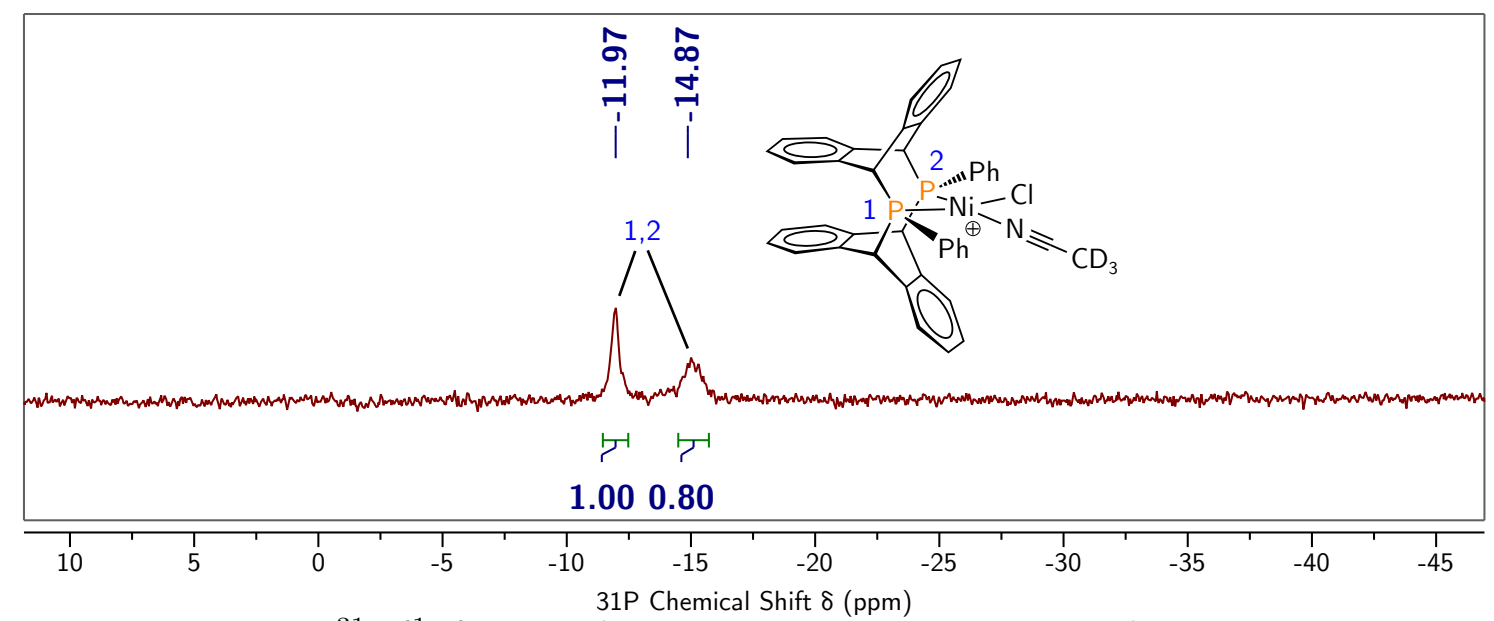

Figure S.20: ${ }^{31} \mathrm{P}\left\{{ }^{1} \mathrm{H}\right\}$ NMR $\left(203 \mathrm{MHz}\right.$, acetonitrile- $\left.d_{3}, 25{ }^{\circ} \mathrm{C}\right)$ spectrum of $\mathbf{5}$.

\section{S.1.6 Preliminary Attempts to Synthesize an Organonickel Complex of 3}

\section{S.1.6.1 Treatment of 3 with (tmeda) $\mathrm{NiMe}_{2}$}

A solution of (tmeda) $\mathrm{NiMe}_{2}(20 \mathrm{mg}, 0.098 \mathrm{mmol}, 1.0$ equiv) in THF (2 mL) was added dropwise to a stirring solution of ligand 3 (64 mg, $0.11 \mathrm{mmol}, 1.1$ equiv) in THF (2 mL). After the solution stirred for $24 \mathrm{~h}$ at $23{ }^{\circ} \mathrm{C}$, all volatile materials were removed under reduced pressure and the resulting residue was taken up in benzene- $d_{6}$ for NMR analysis. Resonances assigned to $\mathbf{3}$, anthracene, and (tmeda) $\mathrm{NiMe}_{2}$ are present in the ${ }^{1} \mathrm{H}$ NMR spectrum (Fig. S.21) and a signal assigned to 3 is present in the ${ }^{31} \mathrm{P}\left\{{ }^{1} \mathrm{H}\right\}$ NMR spectrum (Fig. S.22).

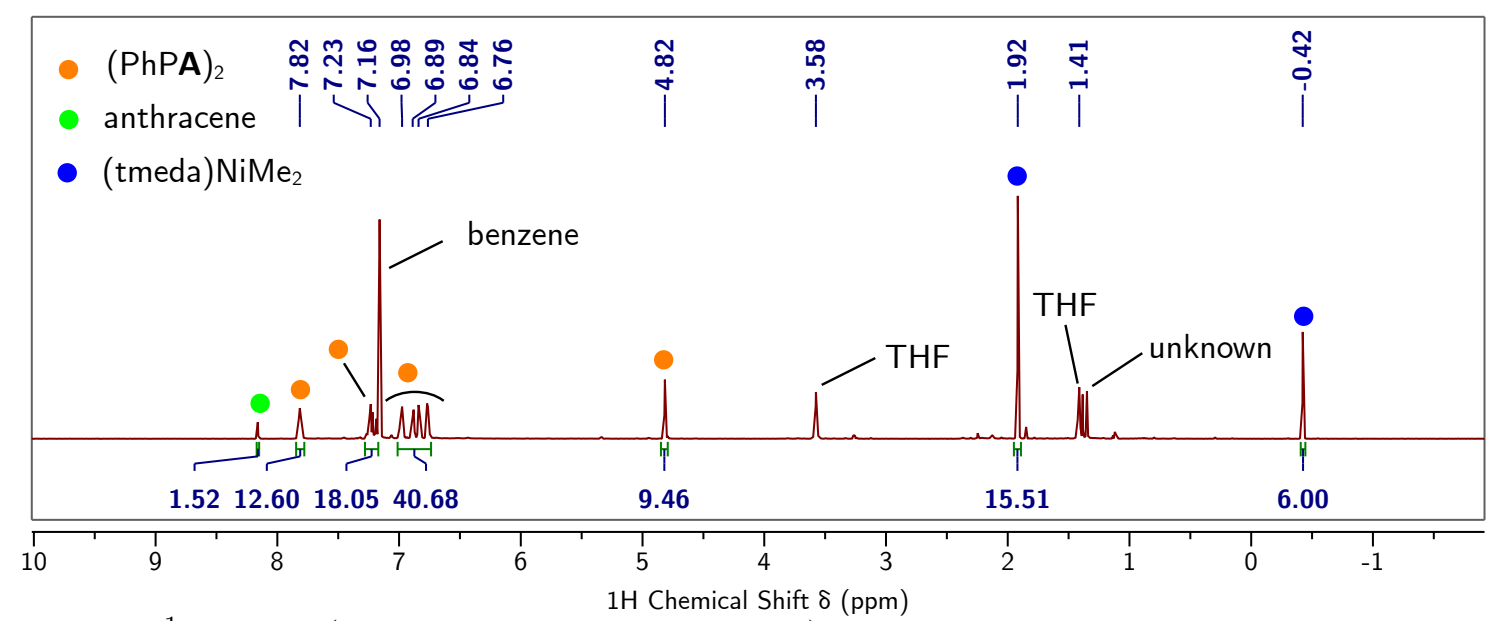

Figure S.21: ${ }^{1} \mathrm{H}$ NMR $\left(500 \mathrm{MHz}\right.$, benzene- $\left.d_{6}, 25{ }^{\circ} \mathrm{C}\right)$ spectrum of the crude reaction mixture after treating ligand 3 with (tmeda) $\mathrm{NiMe}_{2}$. 


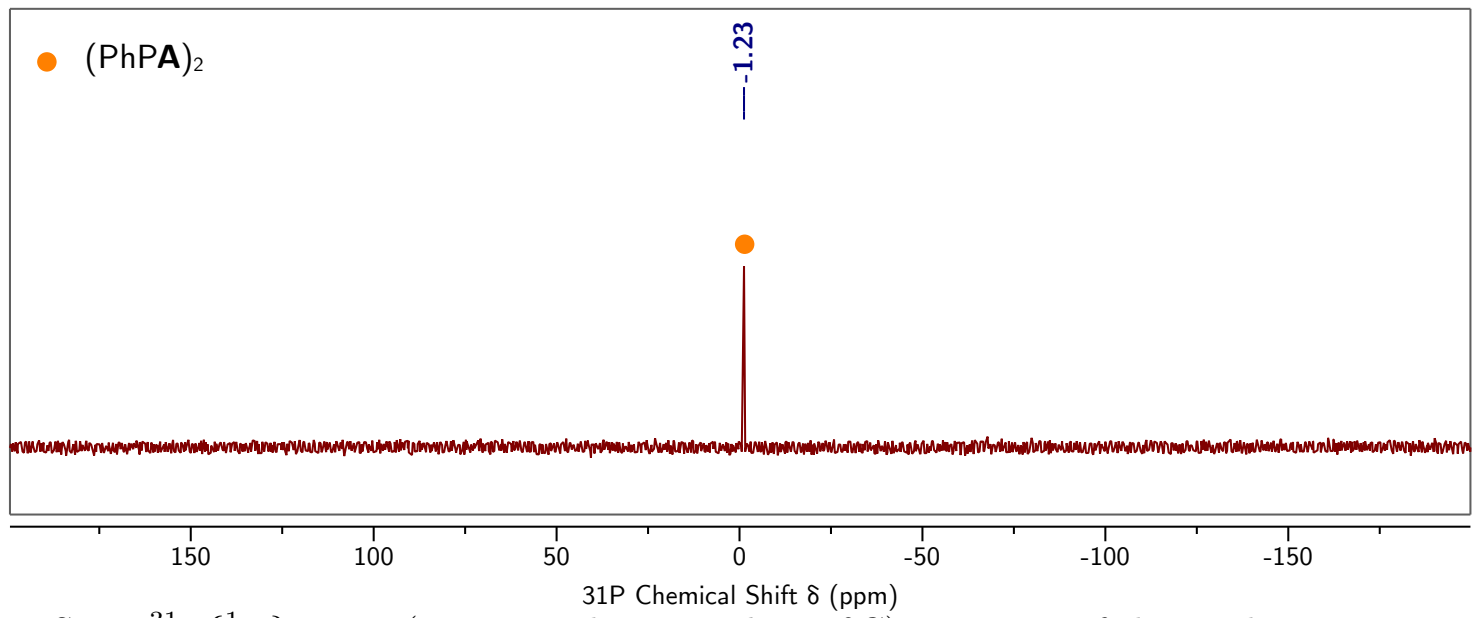

Figure S.22: ${ }^{31} \mathrm{P}\left\{{ }^{1} \mathrm{H}\right\}$ NMR $\left(121 \mathrm{MHz}\right.$, benzene- $\left.d_{6}, 25{ }^{\circ} \mathrm{C}\right)$ spectrum of the crude reaction mixture after treating ligand $\mathbf{3}$ with (tmeda) $\mathrm{NiMe}_{2}$.

\section{S.1.6.2 Treatment of 4 with Methylmagnesium Bromide}

A $0.3 \mathrm{M}$ diethyl ether solution of methylmagnesium bromide $(0.18 \mathrm{~mL}, 0.056 \mathrm{mmol}, 2.0$ equiv) was added dropwise to a stirring solution of 4 (20 mg, $0.028 \mathrm{mmol}, 1.0$ equiv) in THF (2 mL). The solution stirred for $20 \mathrm{~min}$ at $23{ }^{\circ} \mathrm{C}$, during which the reaction mixture became red. An aliquot was removed for ${ }^{31} \mathrm{P}\left\{{ }^{1} \mathrm{H}\right\}$ NMR analysis and signals corresponding $\left[(\mathrm{PhPA})_{2}\right] \mathrm{Ni}(\mathrm{Me}) \mathrm{Cl}$ and $\left[(\mathrm{PhPA})_{2}\right] \mathrm{Ni}(\mathrm{Me})_{2}$ were observed (Fig. S.23). All volatile materials were removed from the reaction mixture and the resulting black residue was taken up in benzene- $d_{6}$ for NMR analysis. Signals corresponding to anthracene are present in the ${ }^{1} \mathrm{H}$ NMR spectrum (Fig. S.24).

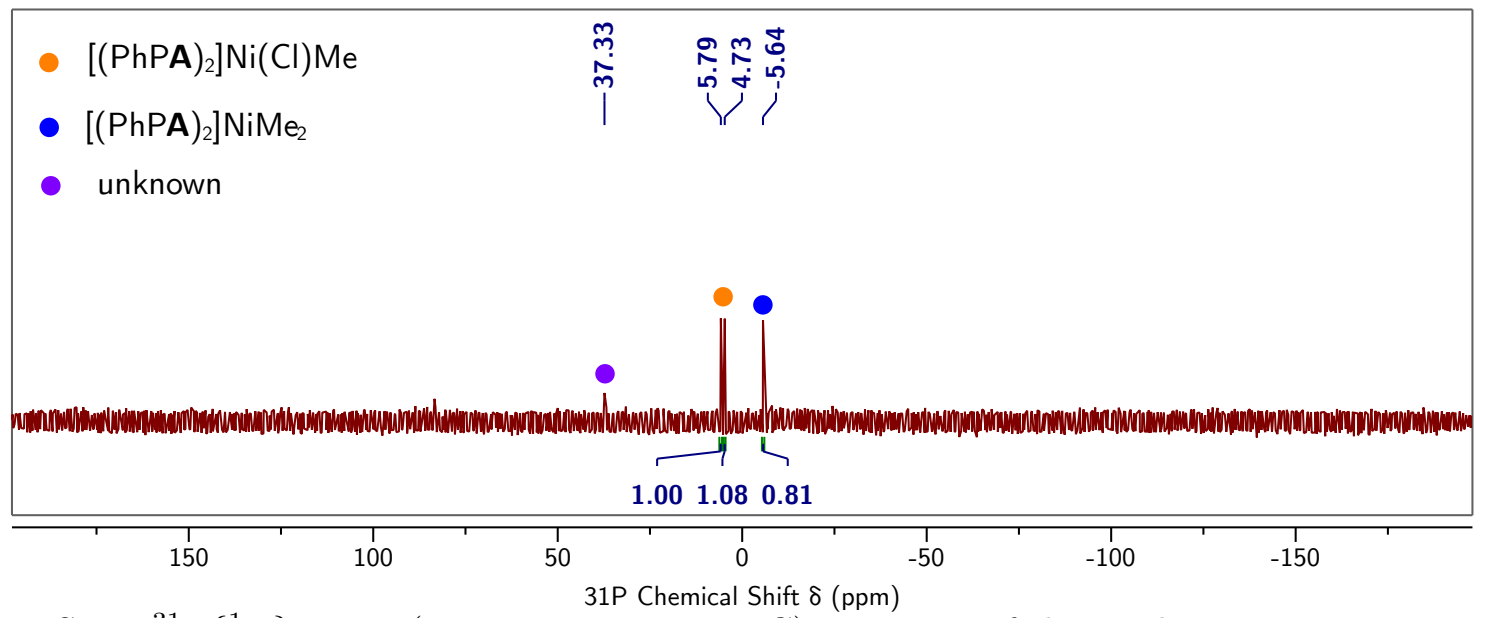

Figure S.23: ${ }^{31} \mathrm{P}\left\{{ }^{1} \mathrm{H}\right\}$ NMR (162 MHz, THF, $\left.25{ }^{\circ} \mathrm{C}\right)$ spectrum of the crude reaction mixture after treating compound $\mathbf{4}$ with methylmagnesium bromide. 


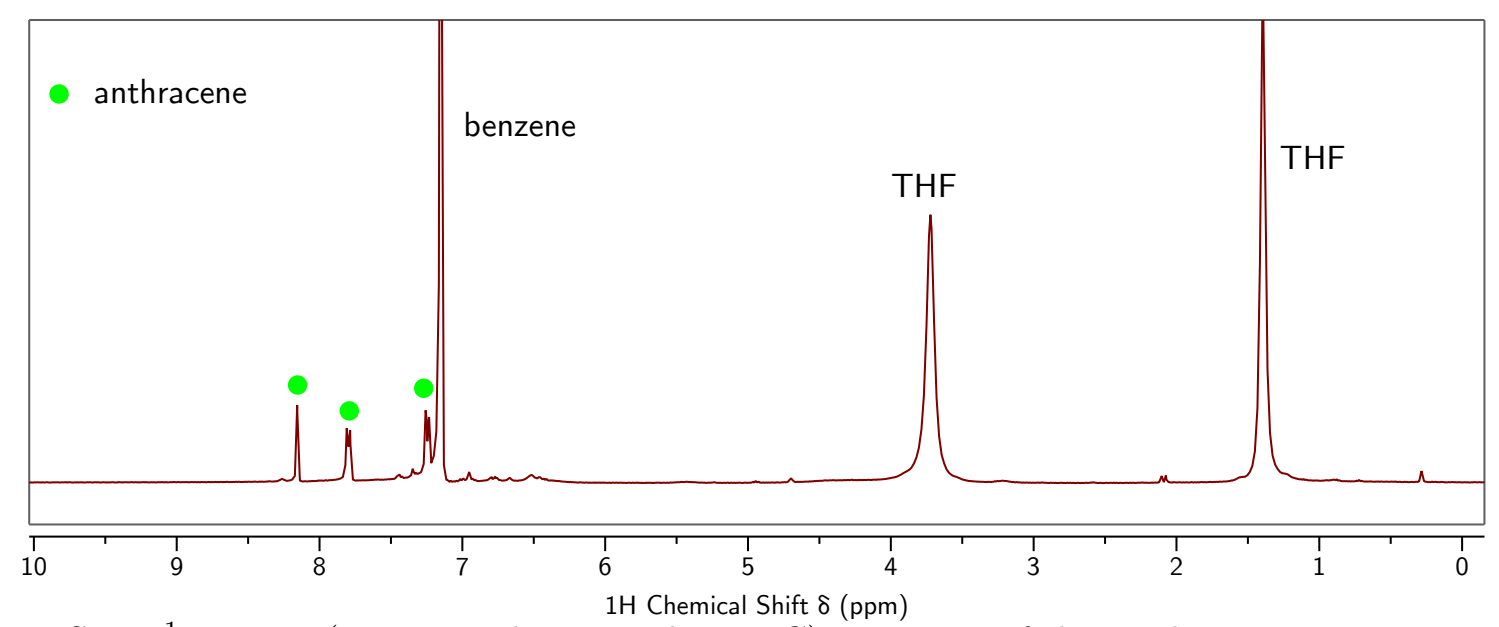

Figure S.24: ${ }^{1} \mathrm{H}$ NMR (400 MHz, benzene- $d_{6}, 25{ }^{\circ} \mathrm{C}$ ) spectrum of the crude reaction mixture after treating compound $\mathbf{4}$ with methylmagnesium bromide.

\section{S.1.6.3 Treatment of 4 with Trimethylaluminum}

To a thawing solution of 4 (25 mg, 0.034, 1.0 equiv) in toluene- $d_{8}(1 \mathrm{~mL})$ was added a $1 \mathrm{M}$ hexanes solution of trimethylaluminum $(0.034 \mathrm{~mL}, 0.034 \mathrm{mmol}, 1.0$ equiv) dropwise. Immediately, the reaction mixture became deep red. After the mixture stirred as it warmed to $23{ }^{\circ} \mathrm{C}$ over $1 \mathrm{~h}$, the mixture was filtered through a pipette containing a plug of microfiber filter paper into an NMR tube. Resonances assigned to unknown byproducts were observed in the ${ }^{1} \mathrm{H}$ NMR and ${ }^{31} \mathrm{P}\left\{{ }^{1} \mathrm{H}\right\}$ NMR spectra (Fig. S.25 and Fig. S.26). Signals assigned to anthracene were also observed in the ${ }^{1} \mathrm{H}$ NMR spectrum.

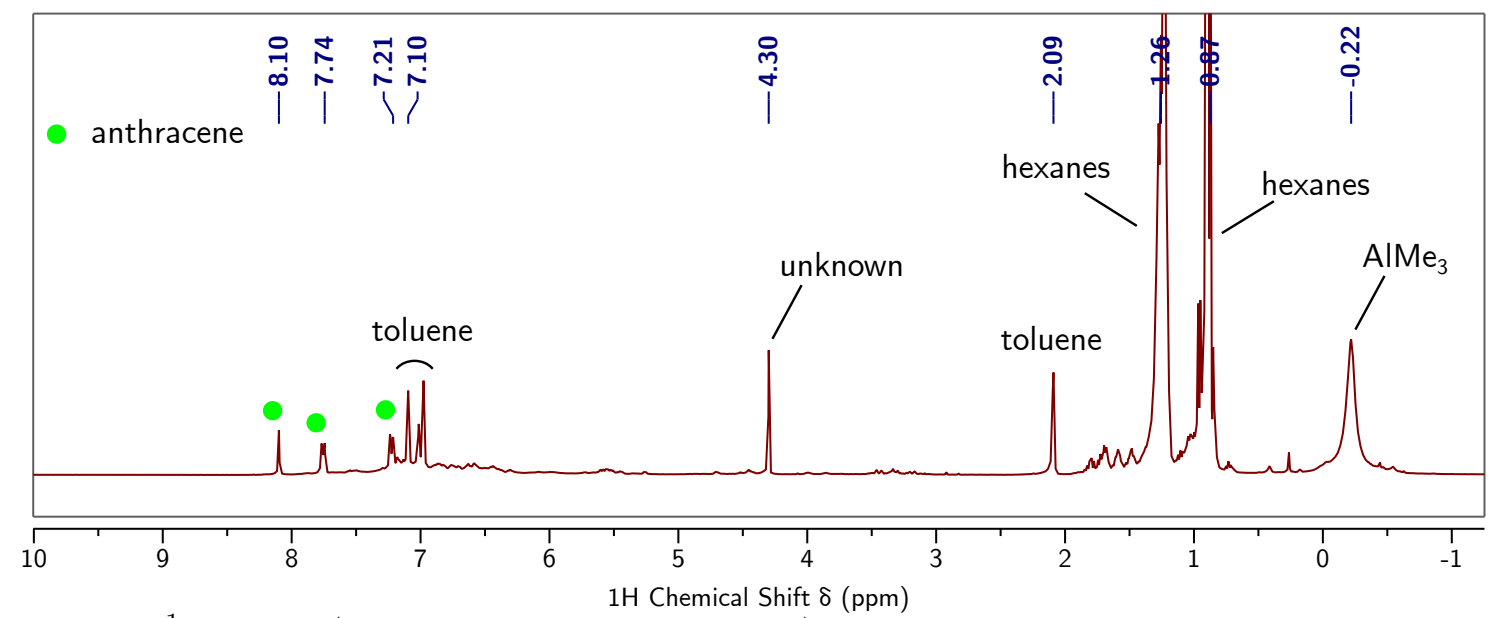

Figure S.25: ${ }^{1} \mathrm{H}$ NMR $\left(400 \mathrm{MHz}\right.$, toluene- $\left.d_{8}, 25{ }^{\circ} \mathrm{C}\right)$ spectrum of the crude reaction mixture after treating compound $\mathbf{4}$ with trimethylaluminum. 


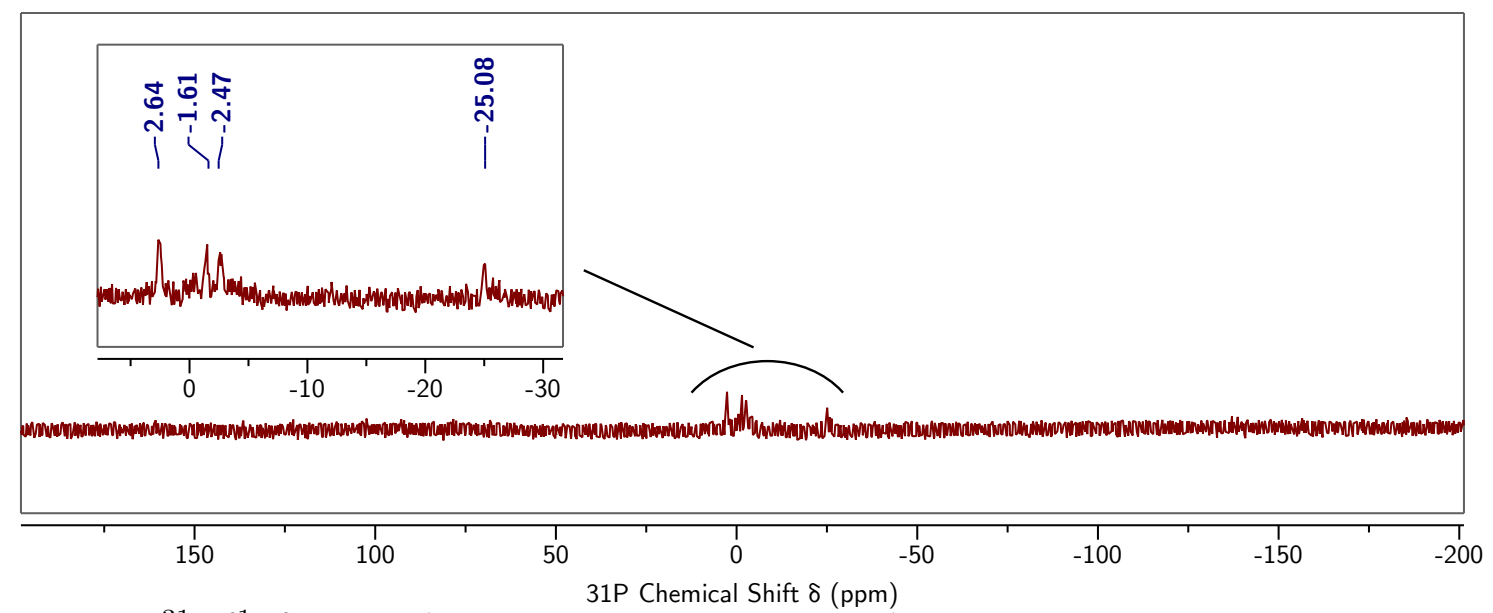

Figure S.26: ${ }^{31} \mathrm{P}\left\{{ }^{1} \mathrm{H}\right\}$ NMR $\left(162 \mathrm{MHz}\right.$, toluene- $\left.d_{8}, 25{ }^{\circ} \mathrm{C}\right)$ spectrum of the crude reaction mixture after treating compound 4 with trimethylaluminum.

\section{S.2 X-Ray Diffraction Studies}

Single crystals suitable for X-ray diffraction were transferred from the glovebox under Paratone oil onto a microscope slide. A crystal was selected under a microscope and mounted in hydrocarbon oil on a nylon loop. Low-temperature $(100 \mathrm{~K})$ data were collected on a Bruker-AXS X8 Kappa Duo diffractometer with $I \mu S$ micro-sources, coupled to a Photon 3 CPAD detector using Mo $K_{\alpha}$ radiation $(\lambda=0.71073 \AA)$ with $\phi$ - and $\omega$-scans. The structures were solved by dual-space methods using SHELXT[30] and refined against $F^{2}$ on all data by full-matrix least squares with SHELXL-2017[30] following established refinement strategies.[31] All non-hydrogen atoms were refined anisotropically. All hydrogen atoms were included into the model at geometrically calculated positions and refined using a riding model. The isotropic displacement parameters of all hydrogen atoms were fixed to 1.2 times the $U$-value of the atoms they are linked to $(1.5$ times for methyl groups). Descriptions of the individual refinements follow below and details of the data quality and a summary of the residual values of the refinements for all structures are given in Tables S.1 and S.2. Further details can be found in the form of .cif files available from the CCDC.

Single crystals of $[\mathbf{2}] \mathrm{AlCl}_{4}$ were grown from dichloromethane at $-35^{\circ} \mathrm{C}$. The structure was solved in the triclinic space group $P \overline{1}$ with two molecules of $[\mathbf{2}] \mathrm{AlCl}_{4}$ and one molecule of dichloromethane in the asymmetric unit. One molecule of $[2] \mathrm{AlCl}_{4}$ exhibits whole molecule disorder and was disordered accordingly. Disorders were refined with the help of similarity restraints on 1,2 and 1,3 distances. Single crystals of $\mathbf{3}$ were grown by vapor diffusing $\mathrm{Et}_{2} \mathrm{O}$ into a saturated solution of 
3 in dichloromethane. The structure was solved in the triclinic space group $P \overline{1}$ with one molecule of $\mathbf{3}$ and no solvent molecules in the asymmetric unit. The molecule exhibits no disorder. Single crystals of 4 were grown from a solution of dichloromethane. The structure was solved in the orthorhombic space group Pbcn with half a molecule of $\mathbf{4}$ and half a molecule of dichloromethane. The molecule exhibits no disorder. Single crystals of $\mathbf{5}$ were grown from ortho-dichlorobenzene at $23{ }^{\circ} \mathrm{C}$. Compound 5 crystallized in the tetragonal space group $P 4_{2} / m b c$ with with one quarter of the cation and one entire anion in the asymmetric unit. The cationic portion was refined as a half cation $\left[\left[(\mathrm{PhPA})_{2}\right] \mathrm{NiCl}\right]^{+}$constrained to $50 \%$ occupancy over special positions to treat the 50-50 disorder over the mirror plane with the help of similarity restraints on 1-2 and 1-3 distances and displacement parameters as well as rigid bond restraints for anisotropic displacement parameters. 


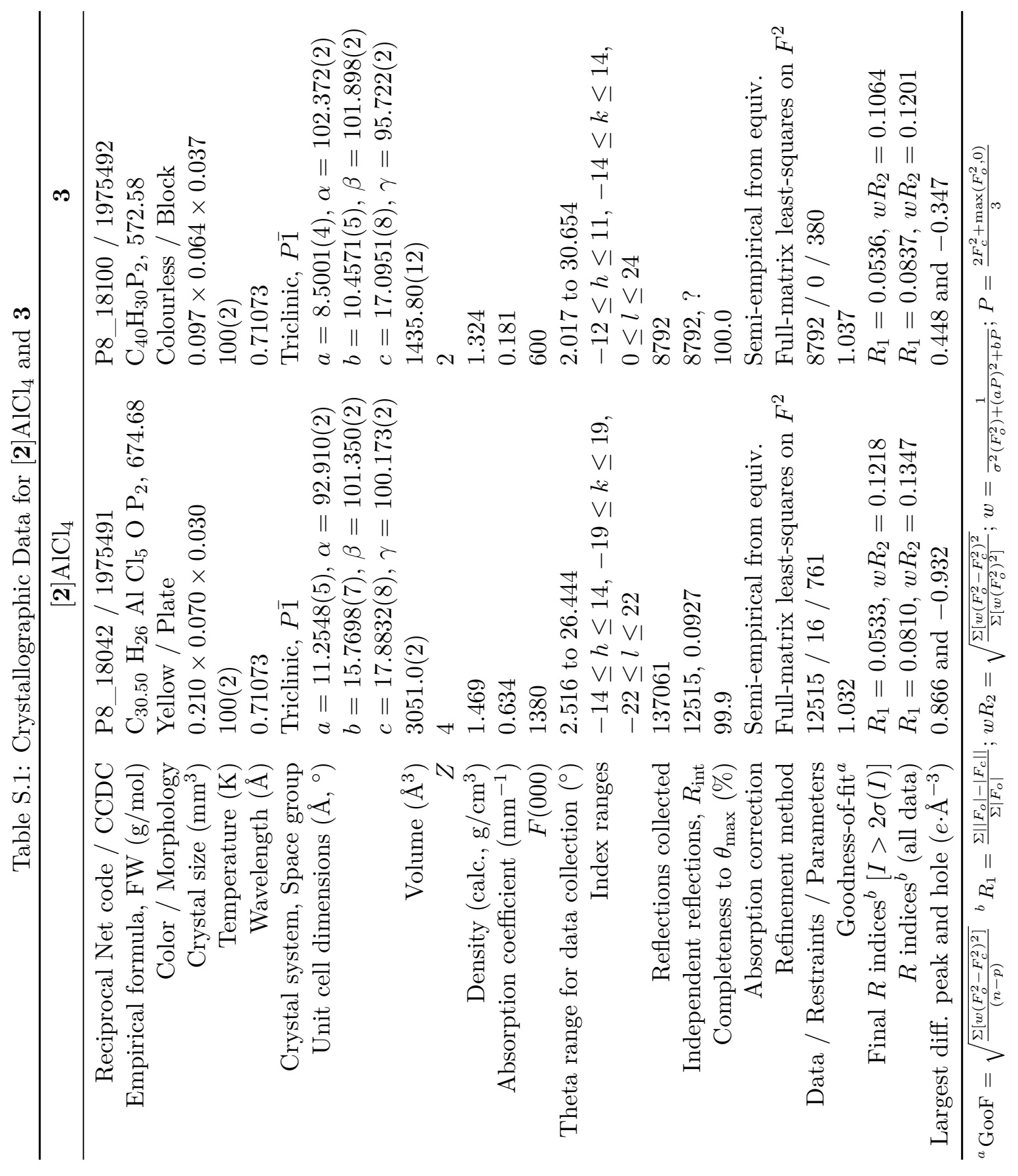




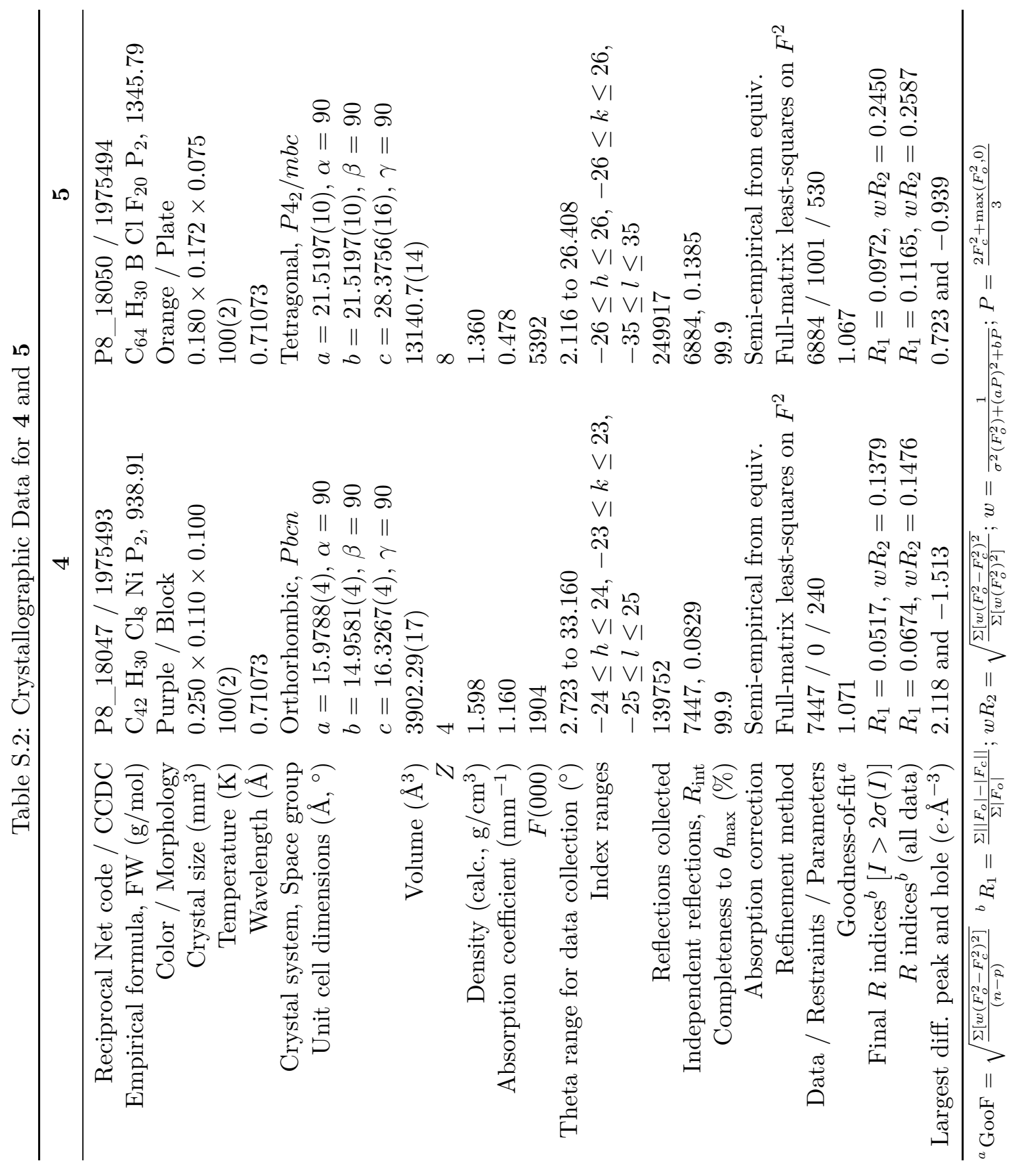




\section{References}

[25] Pangborn, A. B.; Giardello, M. A.; Grubbs, R. H.; Rosen, R. K.; Timmers, F. J. Safe and Convenient Procedure for Solvent Purification. Organometallics 1996, 15, 1518-1520.

[26] Williams, D. B. G.; Lawton, M. Drying of Organic Solvents: Quantitative Evaluation of the Efficiency of Several Desiccants. J. Org. Chem. 2010, 75, 8351-8354.

[27] Kaschube, W.; Pörschke, K. R.; Wilke, G. tmeda-Nickel-Komplexe: III. ( $N, N, N^{\prime}, N^{\prime}-$ Tetramethylethylendiamin)-(dimethyl)nickel(II). J. Organomet. Chem. 1988, 355, 525-532.

[28] Fulmer, G. R.; Miller, A. J. M.; Sherden, N. H.; Gottlieb, H. E.; Nudelman, A.; Stoltz, B. M.;

Bercaw, J. E.; Goldberg, K. I. NMR Chemical Shifts of Trace Impurities: Common Laboratory Solvents, Organics, and Gases in Deuterated Solvents Relevant to the Organometallic Chemist. Organometallics 2010, 29, 2176-2179.

[29] Hanwell, M. D.; Curtis, D. E.; Lonie, D. C.; Vandermeersch, T.; Zurek, E.; Hutchison, G. R. Avogadro: an advanced semantic chemical editor, visualization, and analysis platform. $J$ Cheminformatics 2012, 4:17, 1-17.

[30] Sheldrick, G. M. SHELXT - Integrated space-group and crystal-structure determination. Acta Cryst. A 2015, 71, 3-8.

[31] Müller, P. Practical suggestions for better crystal structures. Crystallogr. Rev. 2009, 15, $57-83$. 